\title{
Was the Great Depression of 1929 Harsher than the Greek Depression?
}

\author{
${ }^{1}$ Pantelis Sklias, ${ }^{2}$ Spyros A. Roukanas, ${ }^{\dagger}$ Georgios Galatsidas
}

${ }^{1}$ Professor, Neapolis University Pafos, 2, Danaes Avenue, Pafos 8042, Cyprus

${ }^{2}$ Assistant Professor, Department of International and European Studies, University of Piraeus 126 Gr. Lampraki Str., Piraeus, 18534 , Greece

${ }^{3}$ Visiting Lecturer, Department of Financial and Management Engineering, University of the Aegean, Chios.

\begin{tabular}{|c|c|}
\hline ARTICLE INFO & ABSTRACT \\
\hline Article History & \multirow{6}{*}{$\begin{array}{l}\text { Purpose: } \\
\text { This paper is an analysis based on the comparison of the Greek Depression with the Great } \\
\text { Depression of } 1929 \text { in the US. } \\
\text { Design/methodology/approach: } \\
\text { This analysis does neither focus on the pre-crisis period, nor on the manifestation of the } \\
\text { crisis or the structural problems and economic policies that rendered the Greek economy } \\
\text { vulnerable when the financial turmoil broke out. An entire decade has passed since the onset } \\
\text { of the crisis, and various policies have been implemented, with explicitly stated goals and } \\
\text { specific results. A clear distinction is made between these two periods, which appear to be } \\
\text { relatively independent. The causes of the crisis itself are different than the causes that } \\
\text { turned the crisis into a prolonged depression with irreversible consequences for the } \\
\text { economy and the society. } \\
\text { Finding: }\end{array}$} \\
\hline & \\
\hline Received 2 July 2021 & \\
\hline $\begin{array}{l}\text { Accepted } 17 \text { November } \\
2021\end{array}$ & \\
\hline \multirow[t]{6}{*}{$\begin{array}{l}\text { JEL Classifications } \\
\text { Foo, E3o, E60 }\end{array}$} & \\
\hline & \\
\hline & $\begin{array}{l}\text { The comparison of the two crises on the basis of their effects on the real economy } \\
\text { demonstrates that the Greek crisis had harsher consequences than the US crisis, taking into } \\
\text { account its impact on key macroeconomic aggregates such as the income loss, the duration } \\
\text { of the depression, the unemployment, the stock market index. }\end{array}$ \\
\hline & Research limitations/implications: \\
\hline & This paper takes into account that Greece is a member state of Eurozone, on the other hand \\
\hline & $\begin{array}{l}\text { U.S.A had an autonomous monetary policy during the Great Depression. } \\
\text { Originality/value: }\end{array}$ \\
\hline & The stubborn implementation of the "bailout" programme for the Greek economy not only \\
\hline & has failed to produce the expected results as regards the debt and the deficits, but has also \\
\hline & had devastating effects on the real economy. In addition, we ought to focus on the lack of \\
\hline $\begin{array}{l}\text { Economic recession; Public } \\
\text { debt crisis; Fiscal crises; } \\
\text { Effects of the crisis on the }\end{array}$ & $\begin{array}{l}\text { national planning and a carefully planned actual and sustainable development of the real } \\
\text { economy and, by extension, economic growth. }\end{array}$ \\
\hline
\end{tabular}

Effects of the crisis on the economy and, by extension, economic growth

\footnotetext{
1. Introduction

The depression caused by the stock market crash of 1929 is considered to be the worst economic crisis ever to hit the capitalist system in economic history. The main features of that crisis, which justify this description, are its economic and social consequences, duration, intensity, and global reach. The above facts gave rise to the name "Great" Depression. Since then, although the occurrence of economic crises has not been eliminated, this phenomenon has indisputably been contained and, most importantly, its negative economic effects have been limited (debt, deficits, negative GDP growth, unemployment).
} 
The manifestation of the Greek fiscal crisis of 2009-2010 (an endogenous crisis of the capitalist system) and the resulting depression also attract the scientific interest of economists worldwide, owing to its duration, and socioeconomic consequences for Greece. As regards the consequences of the Greek depression, Krugman has claimed that it "has devastated Greece just about as much as defeat in total war devastated imperial German" (Krugman, 2015).

In fact, the stubborn implementation of the "bailout" programme for the Greek economy not only has failed to produce the expected results as regards the debt and the deficits, but has also had devastating effects on the real economy, along with its catastrophic social consequences, as they were crystallised after the manifestation of the crisis and during its management. In this context, the question that often preoccupies the academic community is whether Greece is experiencing a new, harsher 1929 in terms of the effects of its fiscal crisis on the economy and, by extension, on society at large.

Under this prism, the purpose of this paper is the comparative evaluation of the consequences of the Great Depression of 1929 in the US and the Greek fiscal crisis on the real economy and the macroeconomic aggregates (e.g. GDP, debt, deficits, unemployment) of the corresponding countries. The ultimate goal is to highlight the problem faced by the Greek economy. This paper takes into account that Greece is a member state of Eurozone, on the other hand U.S.A had an autonomous monetary policy during the Great Depression.

The thesis of this paper is that the fiscal crisis of the Greek economy has had much more painful and stronger, in terms of intensity and duration, effects on the Greek economy, as compared to the corresponding effects on the US economy following the 1929 Crash. As soon as the Greek economy was hit by the crisis, in fact, the IMF, the EU, and the Greek governments made efforts to deal, as they claim, with the root of the problem, as regards the deficit and debt. Despite these efforts, the problem was amplified (as regards the debt) and, most ominously, the bailout measures caused irreversible damage to the real economy and, in particular, to the productive base.

The questions that we will try to answer in this analysis include: Is Greece experiencing a harsher 1929? Do the prolonged duration of the crisis and its consequences raise concerns about the effectiveness of the "bailout" plans? Should the bailout plans for the Greek economy, along with across-the-board expenditure cuts designed to stabilise budget deficits, also set strategic priorities for a new growth model for Greece?

The paper comprises three parts. The first part consists of a theoretical overview and a critical evaluation of economic crisis theories, and more specifically: a) Financial crises, which are divided into banking and stock market crises; b) public debt crises. The second part discusses the Great Depression of 1929 in the US and the recent Greek fiscal crisis, mostly focusing on exploring their effects on the economy of each country. The third part consists of a comparative evaluation of the effects of the crises on GDP, unemployment, and the time it takes for the economy to recover. The paper is completed with the conclusions and the answer to the resulting research questions.

\section{Theoretical Approach}

\subsection{Definition of business cycles - economic crises - recessions}

In order to facilitate our study, it is useful to define the concepts of business cycles and economic crises. Evidently, total output and productivity do not follow a steady course, albeit grow fast during certain time periods, while decreasing during others. The concept of the business cycle aims at highlighting the various phases of economic growth the economic system goes through (boom-bust-slowdown-depression-stagnation-recovery).

The business cycle, as defined by Wesley Mitchell, comprises four phases, two during the economic expansion period and another two during the contraction period. Starting from the trough of the cycle -stagnation-, we can see a fast improvement that is called recovery. This is followed by an additional expansion that is called prosperity. This phase, in turn, gives its place to a downward trend that results from the occurrence of a crisis. Finally, the crisis is turned into contraction, which is called depression (Howard, 1991:7-11). The term "depression" describes a deep and prolonged downturn of economic activity and a contraction of GDP (negative growth).

Economic crisis theories highlight the factors that interrupt the ascending phase of the business cycle and, in particular, analyse the parameters that lead to the emergence of the crisis during a specific time period. The onset of the crisis finds the economy at the peak of the business cycle. Then, the economy enters the depression phase, as a result of the crisis (Knoop, 2004:27).

In order to facilitate our study, we will attempt, in advance, to classify economic crises based on their causes. So, in terms of context, economic crises are divided into the following main categories: 1) conjunctural and growth crises; 2) inflation crises; 3) structural crises and commodity market bubbles (2008 property market bubble, 17th century "tulip mania”); 4) public debt crises (Greece being a recent case); 5) exchange rate crises (the cases of Russia and South East Asia); 6) financial crises, which are divided into a) banking crises (e.g. the recent 2007/8 financial crisis of in the US) and b) stock market crises. However, crises are quite often of a mixed nature, combining features of more than one category (Kotios and Pavlidis, 2012: 53). Irrespective, though, of the cause of the crisis, the occurrence of the phenomenon has, in all cases, consequences on the real economy, the macroeconomic aggregates, and the people (society), with varying degrees of intensity.

Understanding crises, the cycle, and the cyclical behaviour of the economy is indispensable for exploring the effects of crises on the economy and suggesting policies for dealing with them, as well as for evaluating the policies that are actually implemented. This analysis shall not emphasise on the study of the phenomenon of crises, albeit on the outcomes and magnitude of the depression brought on the economy by both the emergence of the crisis, and the subsequent policies for dealing with it. 
2.2 Sovereign debt crises and their effects on the business cycle

The term "sovereign debt" denotes the sum of the government's financial obligations, which result from the conclusion of loan agreements either by itself, or by agencies under its control. Public loan agreements are usually concluded with the issuance of bonds (transferable securities) (Kotios and Pavlidis, 2012:53). Sovereign debt problems emerge in the case of countries that, with the creditors consent, have borrowed way beyond their means, thus leading to over-indebtedness. Over-indebtedness may lead to the non-sustainability of public debt and, consequently, to a sovereign debt crisis (Woodward, 1992: 23).

A sovereign debt crisis includes the partial, or total, inability to repay debts (Kotios and Pavlidis, 2011:56), the default of the borrower's loan obligations, and the restructuring of the borrower's debts on less favourable, as compared with the original, terms for the lender (Smith, 1776/1999; Reinhart and Roggof, 2010: 6). However, overindebtedness does not automatically and inescapably lead to sovereign default, and the situation may be reversible (Kotios and Pavlidis, 2011: 56).

\subsection{The dynamics of sovereign debt}

The size of a country's sovereign debt is expressed as a percentage of GDP and is affected by the factors of the following equation:

$$
\text { Dt }- \text { dt-1 }=\text { pdt }- \text { ndfst }+(\text { rt-gt }) /(1+g t) d t-1
$$

Source: Pinto and Prasad, 2009: 182

Where $\mathrm{dt}$ is the debt to GDP ratio at the end of a time period, pd is the primary deficit to GDP ratio, rt is the borrowing rate, gt is the real growth rate, and ndfs is the non-debt financing sources to GDP ratio. According to the above function, any changes in the debt to GDP ratio are explained by the primary deficit, the real interest rate, and the real growth rate. There are also other factors, including privatisations as a non-debt financing source, that can play a key role (albeit only as regards the reduction of the debt-to-GDP ratio). The above factors, either individually or combined, can affect the level of debt as a percentage of GDP, being potential causes of over-indebtedness and sovereign debt crisis (Table 1).

Table 1. The determinants of sovereign debt levels

1. $\quad$ Fiscal Deficit $=$ primary deficit + interest payments

2. Nominal debt change $=$ primary deficit + interest payments $-($ sovereign rights + privatisation)

3. Interest payments $=$ nominal interest rate* nominal debt

4. The faster the economy grows, the lower the debt to GDP ratio remains.

5. If part of the debt is denominated in dollars, then a nominal revaluation (or devaluation) will increase (reduce) the debt level in local currency,

6. Moreover, the debt increases when the government is bailing out banks.

Source: Pinto and Prasad, 2009: 185

\subsection{Budget deficits and government borrowing}

The debt is linked to budget deficits via government revenue and expenditure. The fiscal deficit is determined by: 1) the primary deficit (pd) of an economy's government budget (central government revenue minus expenditure); and 2) the loans' servicing costs (determined by the size of a country's total debt and borrowing rate) (Pantelakis, 1995: 25; Krugman, 2008). Economies that show fiscal deficits resort to borrowing in order to cover them. Therefore, the accumulation of primary deficits over time is one of the main reasons behind a ballooning public debt. Moreover, interest payments increase the deficit for the current year and, consequently, total indebtedness (Kazakos et. al., 2016: $51)$.

Based on the above, sovereign debt stabilisation is achieved through the reduction of the fiscal deficit to manageable levels, as well as with the pursuit of strong growth rates. Indeed, as debt is not examined as an absolute figure, but as a percentage of GDP (debt/GDP ratio), any increase in GDP reduces the debt to GDP ratio. 
The emphasis on the analysis of debt crises is due to the fact that they directly lead to the alteration of a country's business cycle, by disrupting its relations with its lenders, as well as to their consequences on its economy and society (Cohn, 2009: 261-164).

\subsection{Financial crises and their effects on the economy}

The term "financial crisis" denotes the sudden and brief deterioration of all, or a set of, financial indicators, such as short-term bank rates, security prices, savings, investment etc. The key features of such crises include bank runs and stock market panics, bank failures and, in general, the failure of a country's financial system. Financial crises are divided into: a) banking crises, and b) stock market crises, although the distinction is not always clear, given the evident interactions between the two types of crises. Moreover, combinations of the two types of financial crisis are a common occurrence (Kotios and Pavlidis, 2012).

\subsection{Banking crises}

The term "banking crises" denotes cases in which banking systems have been beset by: a) raids on banking institution liabilities, for example, bank runs; b) problems with a bank's assets, when there are large drops in the prices of its securities (bubble burst) or increases in non-performing loans (Table 2) (Spartiotis and Stournaras, 2010).

Table 2. Events that define the beginning of a banking crisis

\begin{tabular}{|c|c|c|c|}
\hline $\begin{array}{c}\text { Onset of the banking } \\
\text { crisis }\end{array}$ & $\begin{array}{c}\text { Increasing } \\
\text { banking liabilities }\end{array}$ & \multicolumn{2}{|c|}{ Decreasing banking assets } \\
\hline Events & Bank runs & $\begin{array}{c}\text { Increase in non- } \\
\text { performing loans }\end{array}$ & $\begin{array}{c}\text { Reduction of security and } \\
\text { investment prices (bubble } \\
\text { burst) }\end{array}$ \\
\hline
\end{tabular}

Source: Authors' data

In most banking crises we encounter common causes, which can be divided into two categories: 1) those related to the macroeconomic environment; 2) those related to the structure and operation of the banking system itself. In fact, factors from both the above categories come into play in, and affect the outcome of, all financial crises (Spartiotis and Stournaras, 2010)

As regards the first category, we can say that periods of exogenous macroeconomic instability affect both the borrowers' financial strength and debt repayment capability, with repercussions on bank assets (Kotios and Pavlidis, 2012:97-99). The next paragraphs discuss the exogenous factors that disrupt the external economic environment of the banking system, causing instability.

Sudden shifts in a central bank's monetary and interest rate policy may cause many banks to incur losses, as they have extended a large part of their loans at fixed rates and are forced to borrow at higher costs (Kotios and Pavlidis, 2012:97-99). Moreover, exchange rate crises and exchange rate decreases can also cause bank failures (Pinto and Prasad, 2009). Also, sovereign debt crises in, and the unilateral default of, certain countries can have negative repercussions and disastrous effects on banks holding portfolios that include securities issued by these countries (Pauly, 2005:177-200).

That said, the most usual causes of a banking crisis are internal, and are related to the banks' own speculative operations. The extension of loans, in disregard of quantitative restrictions and qualitative borrower selection criteria, exposes credit institutions to external economic events, as part of their lending portfolio consists of bad loans, and therefore credit institutions are faced with potential defaults by insolvent clients (Agglieta, 2009). The above process may be also triggered by the extremely low interest rates set by the central bank and the growth of money supply in the economy, while we should not overlook the inadequacy of state regulation (Pinto and Prasad, 2009).

The effects of banking crises on the business cycle

The effects of a banking crisis are not limited to the bank itself, i.e. its shareholders and personnel, but also cause problems in the real economy. The real economy is facing refinancing difficulties, investment projects are postponed due to the lack of funding, and business-to-business transactions are obstructed, thus hindering the conduct and growth of commerce on a wider scale. The slowdown of economic activity triggers a vicious spiral of recession and financial difficulty, aggravating banking sector problems (Reinhart and Rogoff, 2009b).

Bank failures are the harbinger of a sovereign debt crisis, since the danger of a financial system collapse makes it necessary for the government to bail out the banking system, in order to save the economy. This way, therefore, private debt becomes public, giving rise to the threat of a sovereign debt crisis. However, this government policy also creates the certainty that banks will be bailed out, thus giving rise to "moral hazard", which leads to the preservation of the banks' reckless lending policies (Kotios and Pavlidis, 2012).

\subsection{Stock market crises}

The term "stock market crisis" denotes a sudden and steep drop of equity prices across a wide range of stock market securities, which leads to a lower price level (Kindleberger, 1978). This harsh adjustment requires a prior strong and unjustified upwards move of equity prices to levels much higher than their actual worth, as a result of increased speculative demand for stock. Therefore, a stock market crisis is the outcome and an integral part of a stock market bubble, which is the antechamber to the crisis itself (Flood and Hodrick, 1990; Diba and Grossman, 1988). Thus, it is 
deemed useful to discuss the concept of asset price bubbles, as an integral part of financial crises. Moreover, our analysis of financial crises is based on Minsky's 5 stages of financial instability: Displacement, Boom, Euphoria, Profittaking, Panic.

\subsection{Stock market bubbles and the emergence of financial crises}

There are various interpretations of the causes of a stock market bubble. A first explanation focuses on an initial increase in security prices (returns), based on actual economic events (i.e., an initial displacement in the economy, which is transmitted to the stock market). This initial upswing in security prices might be caused by exogenous factors and major economic events, such as: a) the discovery and invention of new products, new production methods, and new industries; b) the growth of global demand for a specific asset (prompted by a rise in incomes, also resulting from increased demand for raw materials due to intense production activity, and changes in consumer preferences) (Kotios and Pavlidis, 2012:43-45; Brown, 2011; Kapstein, 1994:58-80).

Whatever the cause of the initial displacement may be, if this is diffused across the economy, it will change the overall economic outlook. Euphoria is also transferred to the stock market, causing an initial and fair, on the basis of actual facts, increase in stock prices (initial displacement) (Minsky, 1982). However, the initial displacement is not enough for the phenomenon to evolve into a bubble. There are also certain additional factors that thrive on the basis of the initial displacement in the economy and the stock market, and, consequently, have an additional and catalytic effect on the completion of the stock market bubble. These factors include: speculation; investor expectations; imitation - herd behaviour; liquidity. Indeed, speculation motivates many consumers to invest in the securities market, in order to benefit from the observed rise in the price of an asset, increasing demand for securities, and sustaining a vicious spiral of security demand and price increases (Kindleberger, 1978:40; Minsky 1982). At the same time, investor expectations regarding the continuation of the rise of stock market prices, enhance and consolidate speculative tendencies among investors, thus having a catalytic effect on the intensification of demand for stock (Walh, 2009).

Imitation and the concept of herd behaviour, also reinforce this trend. Indeed, non-institutional investors, observing other stock market professionals and experts realise profits from speculative deals, also tend to act in the same way, thus spreading the phenomenon of speculative demand (Keynes, 2001:183-184).

Another key parameter that sustains strong demand for securities is the existence of liquidity (monetary policy, in conjunction with the banking system), which enables the transformation of speculative tendencies into action. The credit system enables a part of the population who do not possess adequate funds, to partake in the sale and purchase of securities. Thus, based on all the above, the initial rise in stock prices (displacement) can hatch and grow into a bubble (Kotios and Pavlidis, 2012). The direct consequence, in all the above cases, is the diffusion, of the practice of stock market investment across a large part of the population and, consequently, the excessive growth of demand for securities. Therefore, increased demand for securities leads to further price increases, thus reproducing and intensifying a vicious spiral of price and demand increases, and leading, via this process, to the creation of an asset price bubble (Kindleberger, 1978:40; Minsky, 1982)

Inescapably, the rise of stock market prices is interrupted by various endogenous and/or exogenous factors, leading to a violent adjustment in stock values, which also marks the onset of a stock market crisis (Alexakis and Xanthakis, 2008). Exogenous factors are related to adjustments in the economic environment, which cause an overall reduction of demand for securities.

The endogenous factors that are related to the bursting of the bubble include the concept of herd mentality, which drives investors en masse away from any investments and contributes to the weakening of the bubble. However, the public does not possess any expertise and fills in the gaps in their knowledge by imitating the experts. This factor does not help consolidate the conviction that stability will last, and fuels a disinvestment and asset price reduction mechanism, which leads to the "bursting of the stock market bubble" (Knoop, 2008:78).

The bursting of the bubble may also be caused by massive sales by institutional investors, as part of their speculative activity. More specifically, experts can predict possible changes in the conventional basis of stock evaluation, slightly before the general public. This way they precipitate certain events, by causing them to occur in a more intense way than if they had smoothly evolved. In addition, it has been often observed that experts artificially cause such situations, in order to benefit through their earlier withdrawal (Keynes, 2001:183-184). A banking crisis may also interrupt an asset price bubble, since it reduces the liquidity available for funding speculative demand for the asset. It is also possible that the two factors may interact (Flood and Garber, 1984b).

\subsection{The effects of stock market crises on the business cycle}

A stock market crisis may autonomously trigger the business cycle and lead to depression. To begin with, the bursting of the stock market bubble and the drop in stock prices affect the portfolios of businesses, reduce their wealth thus leading to losses, and lead to the contraction of their investment activity (Kotios and Pavlidis, 2012).

Moreover, the bursting of a stock market bubble quite often, albeit not always, affects the financial sector and its investment-financing function, since it increases the number of business that fail or face financial hardship and, by extension, their ability to repay their loans. It also reduces the net value of bank securities, as well as the value of the stock market products held by banks, for either collateral or investment purposes. Therefore, there is a close and interactive relationship between asset price bubbles, and stock market and banking crises (Kotios and Pavlidis, 2012)

In summary, the theoretical review of economic crises and, in particular, sovereign debt crises aims at providing us with the interpretative tools required for analysing the economic crises in the US and Greece, in order to study their effects on the economy. 


\section{The stock market crash of 1929 in the U.S. and the great depression}

The Great Depression that befell the US as a result of the financial crisis of 1929-30 is among the harshest of the past hundred years, given its impact on the economy and the society. It is indeed telling that, even today, there is vibrant interest in the study of that phenomenon, since it is a milestone in the evolution of economics and a yardstick for all economic crises that have occurred until this date (Bernanke, 2000). This section will deal with the consequences of the 1929 crisis on the real economy of the US, after a brief discussion of its type, features, and causes.

\subsection{Causes of the 1929 financial crisis in the US}

Any effort to analyse the depression in the US economy in 1929 requires a study of both the causes of the financial crisis of 1929, and the macroeconomic situation prevailing in the US during the 1920s, before the onset of the financial crisis.

The 1920s saw significant economic growth. Indeed, there has been constant GDP and, therefore, constant GDP per capita growth since 1921, as shown in Figure 1, reflecting economic prosperity and the prevalence of strong demand across the economy.

This was accompanied by price stability, as shown in Figure 2 with the use of the Consumer Price Index (CPI, shows the price mobility of consumer staples purchased during a period of time) and the Wholesale Price Index (WPI, shows the cost of purchases for businesses, wholesale price).

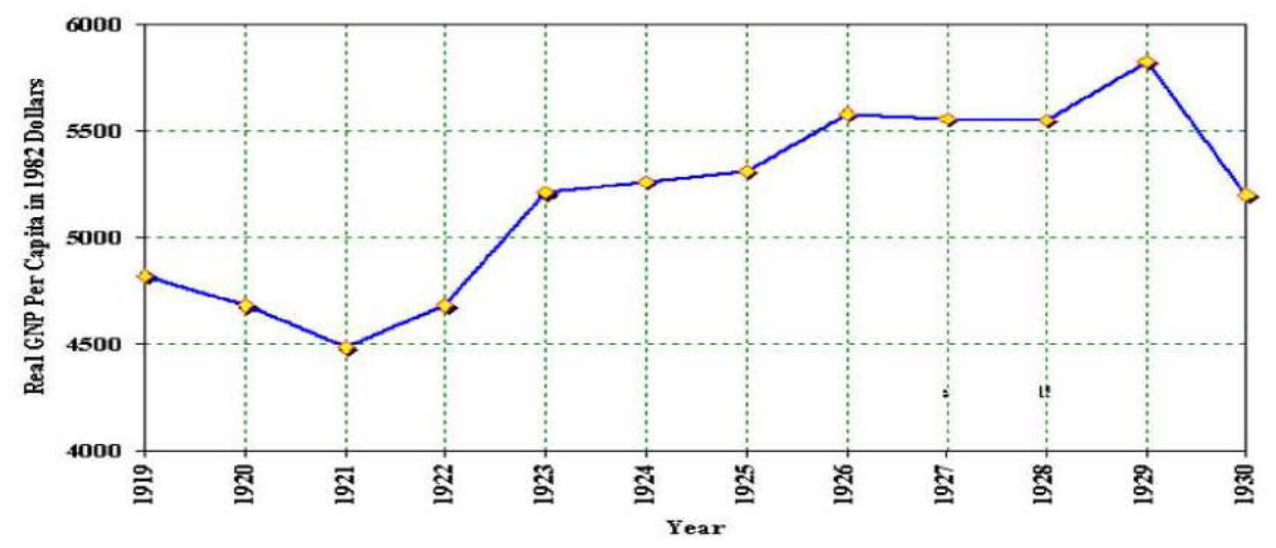

Figure 1. Per capita Gross National Product, US, 1919-1930

Source: Smiley, 2007

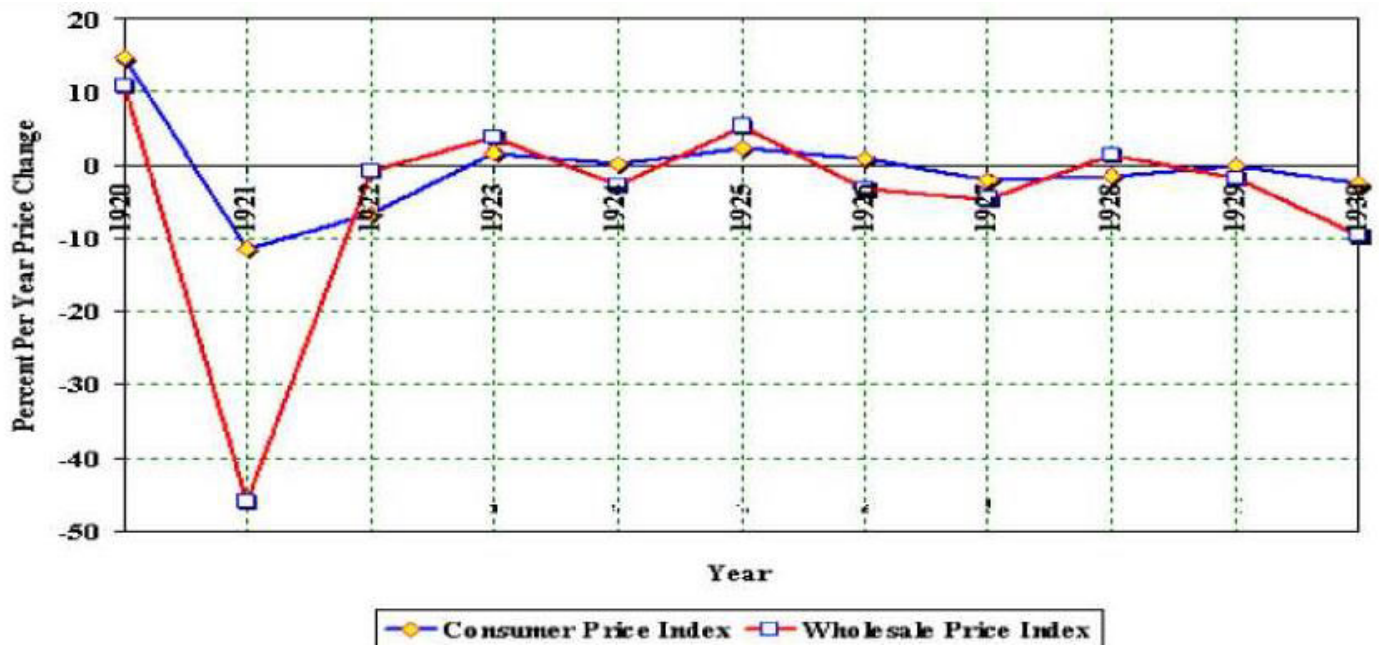

Figure 2. Price changes, US, 1920-1930

Source: Smile, 2007

Economic growth was the result of the industrial boom of that time. Indeed, the Industrial Production Index of the US Federal Reserve (Fed), which averaged at 67 (against a base of 100) during 1923-1925, rose to 110 in July 1928 , and to 126 in June 1929. Strong industrial growth was, among other things, the outcome of the discovery of 
new products, and the creation of new industries (such as automobiles, electrical appliances, the radio etc.) In 1926 , automobile production stood at 4,301,000, and in 1929 it had increased by almost a million units, to 5,358,000, a number that compares favourably with the 5,700,000 new automobiles produced in 1953, a year of abundance (Galbraith, 2000: 23).

Moreover, the adoption of new, innovative production methods, in conjunction with the use of electricity, caused labour and capital productivity to rise, with beneficial effects on business profits. The construction sector also continued to grow, given the incessant increase in demand for the construction of roads and commercial buildings, thus precipitating economic growth (Crafts and Fearon, 2013). It is worth noting that monetary expansion in the US, which was realised through the low interest rates set by the Fed, helped boost economic activity (Kotios and Pavlidis, 2012).

In addition, the change of consumption patterns, because of the growth of per capita GDP and liquidity, further facilitated mass consumption, with positive effects on demand, thus giving rise to a virtuous circle of industrial output, per capita income, and economic growth. The conditions of euphoria in the real economy was transmitted to the stock market, leading to an initial upswing in stock prices, based on actual business profits and the overall economic progress (Reinhart and Rogoff, 2009a).

The combination of high liquidity and promising prospects in the new growing industries, allowed euphoria to take root, leading to the entry of new speculative investors in the stock market, attracted by the rise in stock prices (initial displacement) and the expectations for further growth. According to Galbraith, a representative index for gauging the magnitude of stock market speculation was the volume of trading on margin, which stood at 3,480,780,000 at the end of 1927, 4 billion in June, 5 billion in November, and close to 6 billion at the end of the year. This is how demand for stock and stock market transactions skyrocketed. During the year, a total of 920,550,032 shares changed hands in the New York Stock Exchange. Figure 3 shows the growth of stock and security sales during the 1920s. At the same time, the Dow Jones Industrial Average jumped from 100 points in 1926 to 381 points in September 1929 (its peak). The stock price bubble was a given fact (Galbraith, 2000).
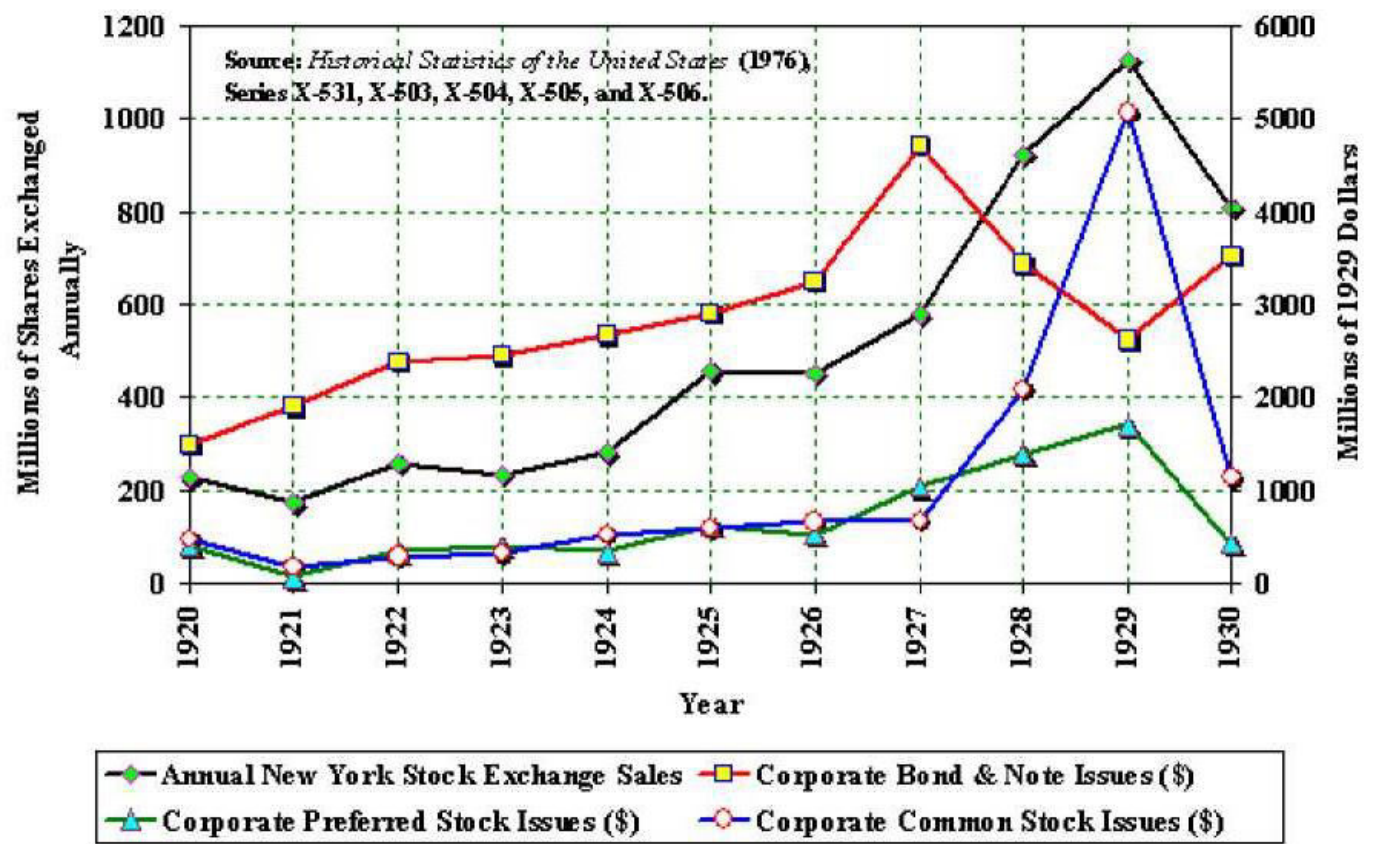

Source: Smiley, 2007

Figure 3. NYSE: Stock and securities sales, 1920-1930

Nevertheless, the rise of stock prices was interrupted when the stock market bubble burst in October 1929. Investor sentiment was reversed, stock prices fluctuated wildly, and panic took hold, urging investors to massive sell-off of shares. Daily stock trading volumes fell to 12.9-16 million shares, with their value almost reduced to zero (Galbraith, 2000).

\subsection{The consequences of the stock market crash - the Great Depression}

Bernanke recognises the correlation between the financial crisis and macroeconomic activity, as he points to the existence of a close relationship between the stages of the financial crisis (most importantly, bank failures) and the changes in output volumes, demonstrating the causal relationship between economic depression and financial crisis (Bernanke, 2000).

Indeed, the initial drop in stock prices caused losses for the portfolios of both businesses and private investors, thus reducing their ability to repay their loans. In fact, the non-performing loan to GDP ratio rose from $9 \%$ to $20 \%$ (Reinhart and Rogoff, 2009a). 
Moreover, the collapse of share prices generated losses for banking portfolios, either because of the securities held by banks as collateral for the extension of loans, or resulting from their own trading in the stock market. The loss of depositor confidence towards the banking system led to four consecutive bank runs. It is worth noting that 744 banks failed in the first 10 months of 1930. By the end of 1933, the number of banks still in operation was slightly above half of the corresponding figure for 1929 As a result of the banking crisis, the provision of credit to the private sector shrank by 50\% during the Depression (Galbraith, 2000) (Figure 4, bank loan fluctuations, 1918-1938).

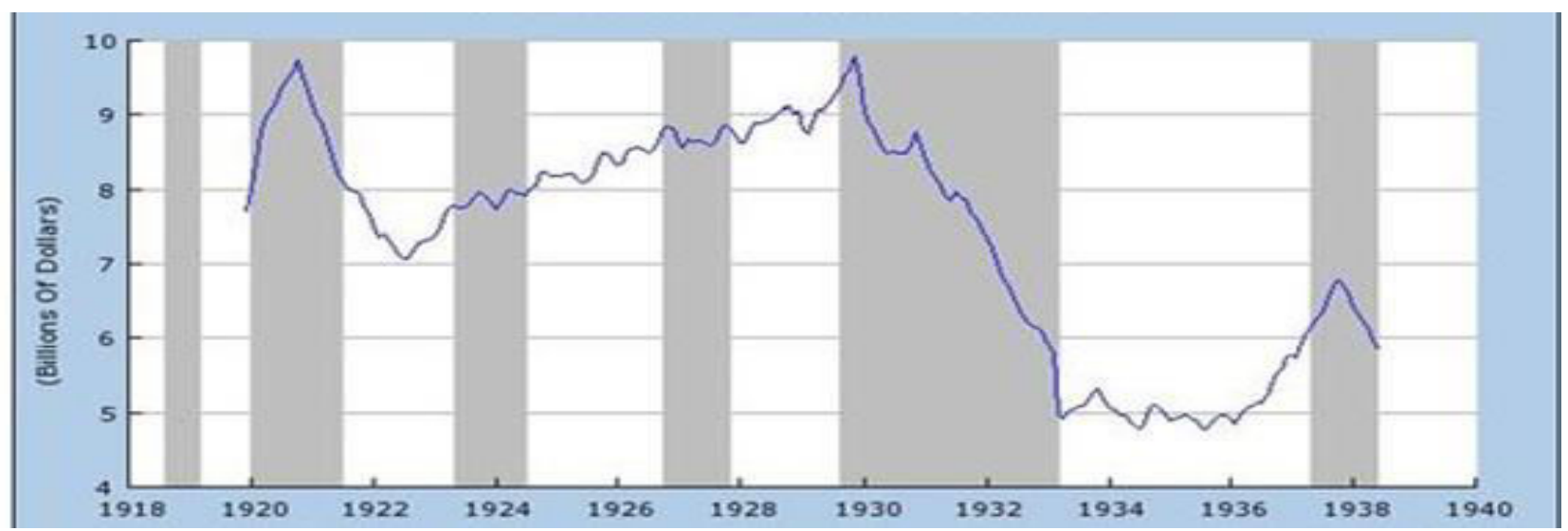

Figure 4. Bank loan fluctuations, 1918-1938

Source: Pettinger, 2012

This financial turmoil was transmitted to the real economy, causing the Great Depression. The initial losses sustained by businesses as a result of their financial activities, combined with the drop in liquidity as a result of the banking crisis, led to the contraction of both business activity and production, causing additional losses and the closure of many businesses, which gave rise to a wave of layoffs. The income loss caused by the drop in share prices reduced consumer expenditure from 16.2 billion US dollars in 1929 to 0.3 billion in 1933. As a result, there was a reduction in total effective demand, which led to a further reduction of total output and, inevitably, to the rise of unemployment. From August 1929 to March 1933 total output fell by 52\%, prices fell by 52\%, and real incomes fell by $35 \%$. Corporate profits, which in 1929 accounted for $10 \%$ of US GDP, turned negative in 1931-2, while private sector investment fell by $87 \%$ (Crafts and Fearon, 2013).

The state of the economy is made clear by the study of the evolution of key macroeconomic aggregates, such as: GDP, unemployment, and inflation. In the first year of the crisis, US GDP fell by 8.5\%, while in 1932 its contraction rate stood at 12.9\%; negative growth persisted for the next 4 years, with the economy having lost 20\% of GDP, while positive growth rates were seen only in the fifth year, which signalled the end of the depression (Galbraith, 2000) (Figures 5 and 6). The decrease in output and, in general, in economic activity led to high unemployment, which peaked in 1932 above 25\% (unemployment fell markedly from the 6th year onwards) (Figure 7). Another feature of the depression was deflation (Figure 8).

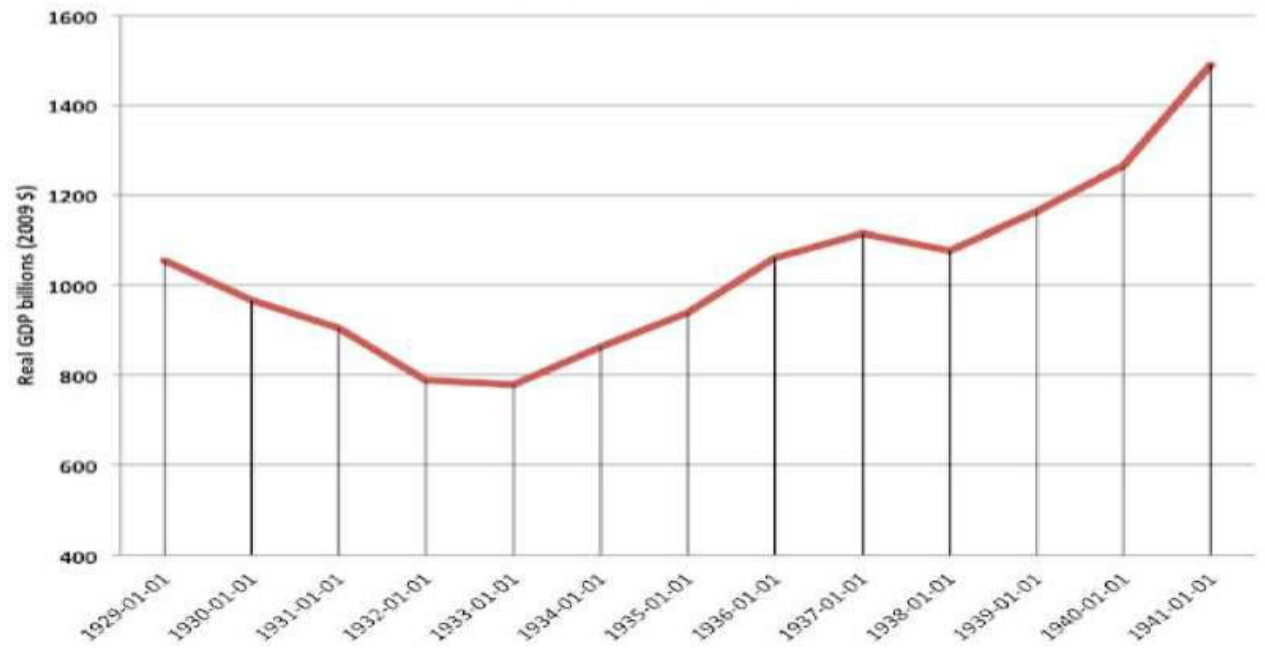

Figure 5. US GDP, 1930-1942

Source: Pettinger, 2012 


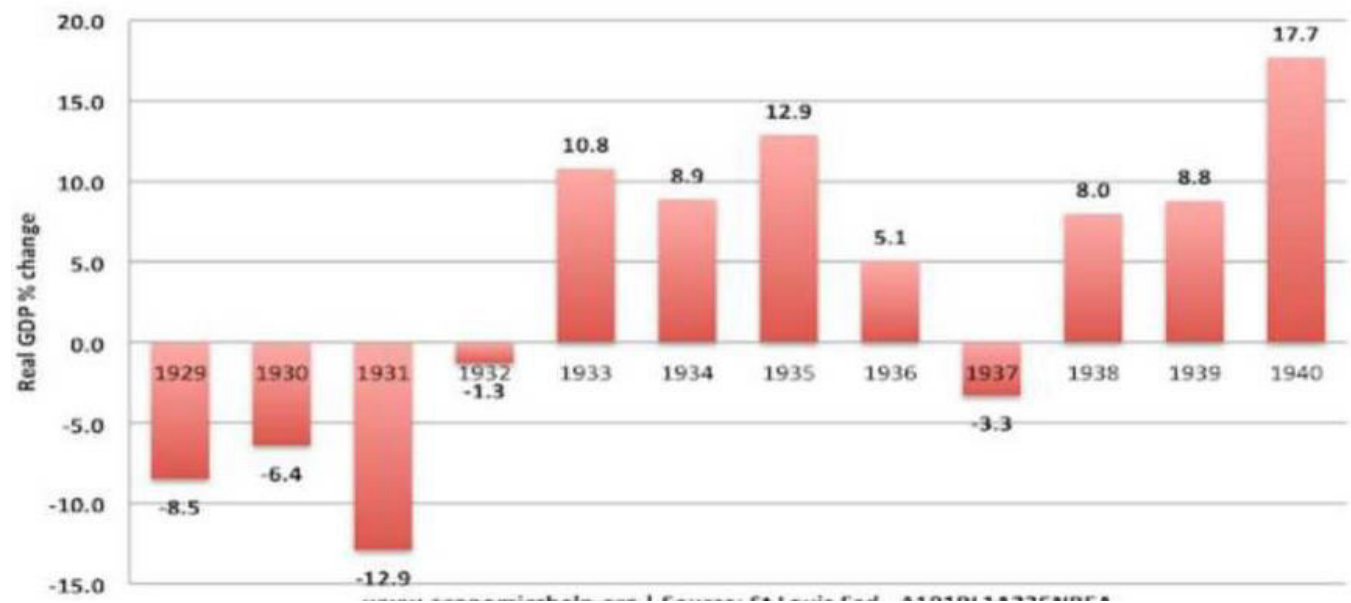

Figure 6. Annual \% Change of US GDP

Source: Pettinger, 2012

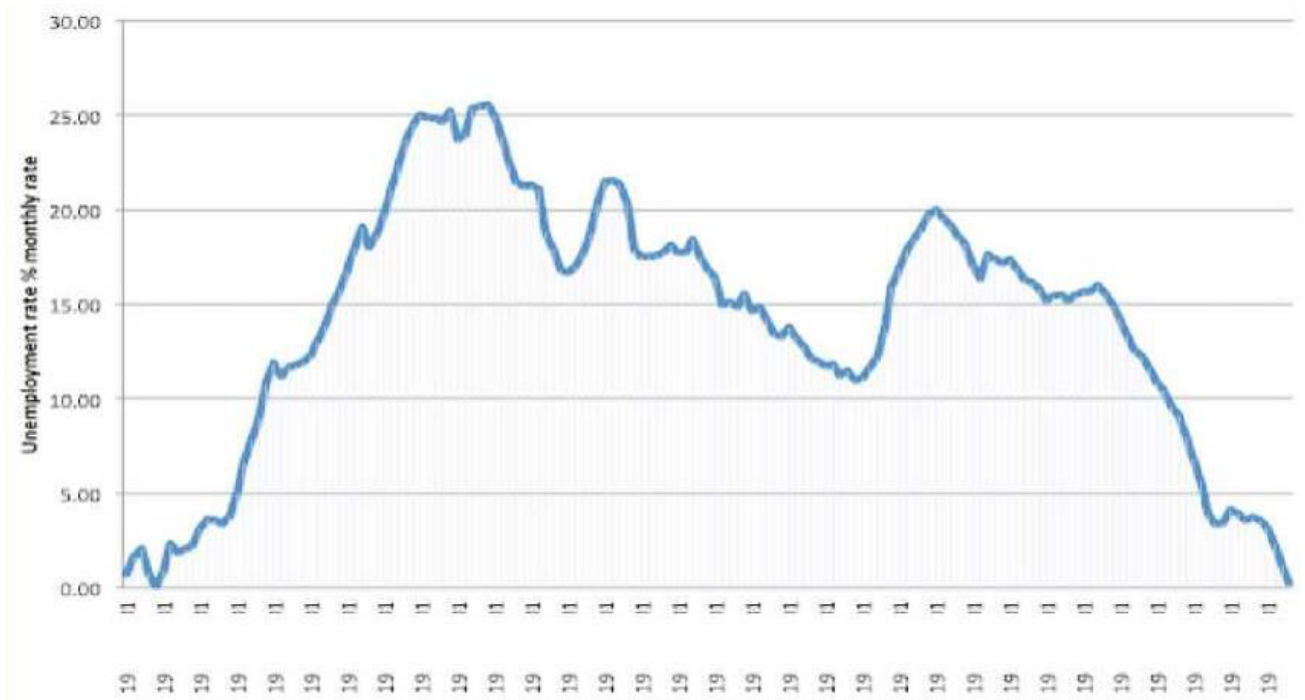

Figure 7. Unemployment fluctuation in the US during the Great Depression

Source: Pettinger, 2012

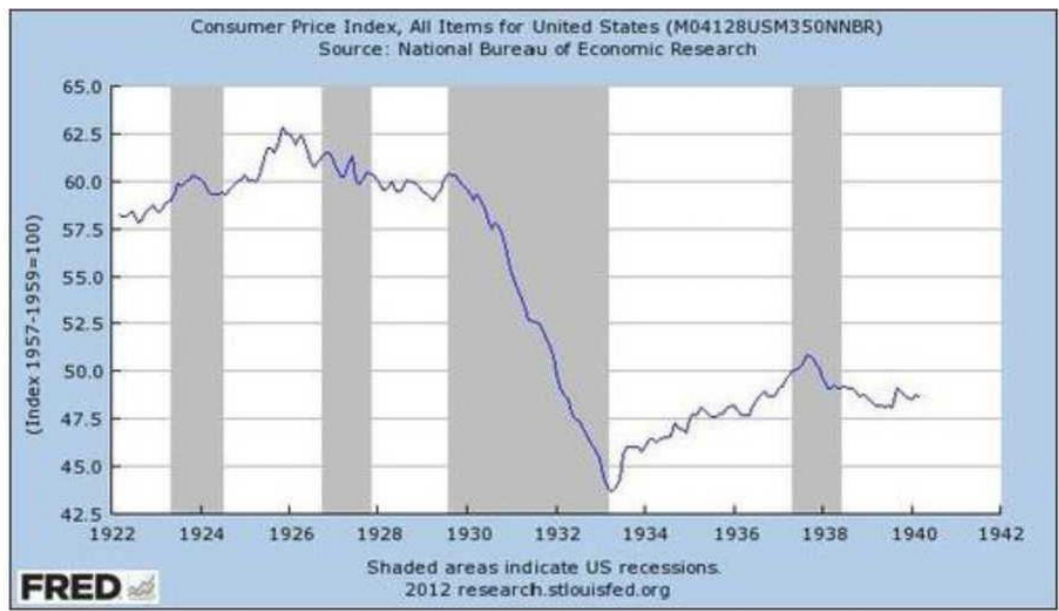

Source: Pettinger, 2012

Figure 8: Consumer Price Index, 1922-1942 


\section{The Greek Fiscal Crisis and Depression}

The main argument of this paper is that Greece's fiscal position over time is characterised by high expenditure and the continuous accumulation of fiscal deficits, without any serious attempt to rationalise and control the multiplier effect of government spending. The direct consequence was a ballooning public debt. Moreover, non-productive spending facilitates the prevalence of an economic growth model that is based on domestic consumption, instead of innovative and extrovert entrepreneurship. This, however, does not only lay the groundwork for over-indebtedness because of the accumulation of deficits in the state budget, but, at the same time, the non-sustainability of a growth that is based on non-productive deficits with low multiplier effects, does not create favourable conditions for the repayment of loans.

\subsection{Macroeconomic aggregates of the Greek economy over time}

The intertemporal analysis of the Greek economy's macroeconomic data, as regards the evolution of primary deficits, public debt, government spending, as well as the qualitative characteristics of realised economic growth, reveals certain parameters of the Greek fiscal crisis. It is a fact that from 1975 to 1979 the Greek economy sustained adequate growth rates, against conditions of fiscal stability. That said, in 1979 and during the next decade there is a marginal increase in GDP (Table 3).

Research on the Eurostat database shows that, up to 1980, the annual fiscal deficit to GDP ratio remained stable and under control, at manageable levels of no more than 3\% of GDP, whereas from 1981 onwards it increased and remained persistently high (with the exception of the run-up to eurozone entry and the achievement of the Maastricht criteria $^{1}$ : deficit at no more than $3 \%$ of GDP and debt at no more of $60 \%$ of GDP) (Table 3 ). However, despite the reduction of interest expenses (owing to the convergence of European interest rates) and despite Greece's almost certain accession to the EMU, primary spending started again to increase, leading to the rise of the public debt to GDP ratio (Karavitis, 2008). Thus, after the country's accession to the EMU and until the onset of the crisis, the deficit was once again strongly on the rise.

The existence of a deficit in the Greek economy means that the general government's primary spending increases faster than its total revenues. ${ }^{2}$ Sophia Dimeli demonstrates that expenses equaled revenues up to the 1970 . In 1980 , public spending stood at $25 \%$ of GDP and, since then, it has been continuously rising, reaching $47 \%$ of GDP, with a less than proportionate increase in revenues (Dimeli, 2010: 74). These persistent fiscal deficits were used for covering consumer spending, even during periods of growth (Alogoskoufis, 2013). Indeed, even in the 1990s, when Greece showed surpluses, these did not result from a reduction of public spending through the rationalisation of resources, but from the growth of public revenues (Argitis, 2012).

Table 3. Growth-development and fiscal deficit, 1975-2010

\begin{tabular}{|c|c|c|c|c|}
\hline \multirow{2}{*}{ Year } & \multicolumn{2}{|c|}{ Growth-development } & \multicolumn{2}{c|}{ Fiscal deficit } \\
\cline { 2 - 5 } & $\begin{array}{c}\text { A) GDP at } \\
\text { constant 2005 } \\
\text { prices (€ bn) }\end{array}$ & $\begin{array}{c}\text { B) Y-O-y } \\
\text { Change (\%) }\end{array}$ & $\begin{array}{c}\text { C) Annual deficit at } \\
\text { constant prices } € \text { bn)(\%) }\end{array}$ & $\begin{array}{c}\text { D) Annual deficit to GDP } \\
\text { ratio }\end{array}$ \\
\hline 1975 & 95.7 & 6.4 & -0.6 & -2.9 \\
\hline 1976 & 102.2 & 6.9 & -0.4 & -1.6 \\
\hline 1977 & 105.2 & 2.9 & -0.8 & -2.5 \\
\hline 1978 & 112.8 & 7.2 & -1.0 & -2.9 \\
\hline 1979 & 116.6 & 3.3 & -0.9 & -2.4 \\
\hline 1980 & 117.3 & 0.7 & -1.0 & -19.0 \\
\hline 1981 & 115.5 & -1.6 & -4.0 & -6.8 \\
\hline 1982 & 114.2 & -1.1 & -3.6 & -7.5 \\
\hline 1983 & 113.0 & -1.1 & -4.0 & -8.3 \\
\hline 1984 & 115.2 & 2.0 & -4.8 & -11.6 \\
\hline 1985 & 118.1 & 2.5 & -6.9 & -9.4 \\
\hline 1986 & 118.8 & 0.5 & -5.1 & -9.1 \\
\hline 1987 & 116.1 & -2.3 & -4.9 & -10.4 \\
\hline 1988 & 121.0 & 4.3 & -6.4 & -12.2 \\
\hline 1989 & 125.6 & 3.8 & -8.4 & \\
\hline
\end{tabular}

$1 \quad$ Makrydakis et. al. (1999), studying data on the Greek economy between 1958-1995, conclude that the Greek fiscal deficit was not manageable. Whereas Katrakilidis and Tabakis (2006) maintain that in 1956-2000 the Greek fiscal deficit was slightly manageable.

2 This paper will only deal with the expenditure side of the Greek economy, without questioning the contribution of the efficient management of the revenue side. 


\begin{tabular}{|l|l|l|l|l|}
\hline 1990 & 125.6 & 0.0 & -10.4 & -14.2 \\
\hline 1991 & 129.5 & 3.1 & 9.4 & -9.9 \\
\hline 1992 & 130.4 & 0.7 & -10.7 & -11.0 \\
\hline 1993 & 128.4 & -1.6 & -7.8 & -8.3 \\
\hline 1994 & 130.9 & 2.0 & -9.1 & -9.1 \\
\hline 1995 & 133.7 & 2.1 & -7.3 & -6.7 \\
\hline 1996 & 136.8 & 2.4 & -7.3 & -5.9 \\
\hline 1997 & 141.8 & 3.6 & -4.7 & -3.9 \\
\hline 1998 & 146.6 & 3.4 & -4.1 & -3.1 \\
\hline 1999 & 151.6 & 3.4 & -5.2 & -3.8 \\
\hline 2000 & 158.4 & 4.5 & -6.5 & -4.5 \\
\hline 2001 & 165.0 & 4.2 & -7.6 & -4.9 \\
\hline 2002 & 170.7 & 3.4 & -9.9 & -5.8 \\
\hline 2003 & 180.8 & 5.9 & -13.8 & -7.5 \\
\hline 2004 & 188.7 & 4.4 & -10.9 & -5.6 \\
\hline 2005 & 193.0 & 2.3 & -12.6 & -6.0 \\
\hline 2006 & 203.7 & 5.5 & -15.1 & -6.8 \\
\hline 2007 & 210.9 & 3.5 & -23.1 & -9.9 \\
\hline 2008 & 210.4 & -0.2 & -36.1 & -15.6 \\
\hline 2009 & 203.8 & -3.1 & -24.0 & -10 \\
\hline 2010 & 193.8 & -4.9 & & \\
\hline
\end{tabular}

Source: European Commission, 2013.

The non-rationalisation of public resources contributes to the maintenance of high expenditure and, consequently, deficits. Indeed, the research by Hauptmeier et. al. (2006) examines fiscal adjustment, the reduction, and the rationalisation of expenditure in different countries in the last three decades. In Greece, the reform and primary spending reduction effort made during the 2000s led to the reduction of the expenditure to GDP ratio by $0.4 \%$ (given the reduction of the country's borrowing costs following its entry in the EMU), while in countries that undertook ambitious reforms and started from more or less the same starting point (as regards the size of public spending) this reduction ranged from 9.7 to 23.3\% (cited in Rapanos, 2008: 167-169). Actually, the rationalisation and containment of expenses are, to a great extent, achieved through the proper implementation of the government budget as an economic policy instrument.

Papadimitriou and Hadjigiannakis argue that in the last three decades the budgets of most ministries show major deviations in terms of realisation. It is indeed telling that, according to the research, realised expenses systematically exceed budgeted ones. This is evidence of the overall wasteful management of public finances, as no due process was adhered to regarding the study of the opportunity cost of each expenditure undertaken by the ministries, or the evaluation of the feasibility of each study in terms of its multiplier effect on economic growth, thus ignoring the need to better utilise available resources (Papadimitriou and Hadjigiannakis, 2010). As a direct consequence, the Greek economy was very wasteful, leading to the emergence of counter-productive deficits.

A continuously growing primary deficit is fed by government borrowing and, consequently, is added to the sovereign debt over time (Rapanos, 2008). In 1975, Greece's sovereign debt stood at 18.2\% of GDP, much lower than the $60 \%$ suggested by the Maastricht treaty as manageable and safe for the economy. In the next decade, Greek debt started its gradual and steady increase, reaching almost 100\% of GDP in the early 1990s and remaining around there until the onset of the crisis (Table 4). However, the unfavourable development of fiscal aggregates (debt and deficit) was accompanied by strong GDP growth, thus affecting the makeup and features of both the GDP, and the economic growth rate. 
Table 4. Public debt to GDP ratio and changes thereof, 1975-2010

\begin{tabular}{|c|c|c|c|c|}
\hline \multirow[t]{2}{*}{ Year } & \multicolumn{4}{|c|}{ Public Debt } \\
\hline & $\begin{array}{c}\text { A) As a } \\
\text { percentage of } \\
\text { GDP }(\%)\end{array}$ & $\begin{array}{c}\text { B) } \mathrm{Y}-\mathrm{O}-\mathrm{y} \\
\text { percentage } \\
\text { change }(\%)\end{array}$ & $\begin{array}{l}\text { C) Absolute figure (at } \\
\text { constant prices, } € \text { bn) }\end{array}$ & $\begin{array}{l}\text { D) Y-o-y change as } \\
\text { a percentage }(\%)\end{array}$ \\
\hline 1975 & 18.2 & - & 3.9 & - \\
\hline 1976 & 17.7 & -2.7 & 4.6 & 17.9 \\
\hline 1977 & 17.9 & 1.1 & 5.2 & 13.0 \\
\hline 1978 & 23.2 & 29.6 & 7.2 & 38.5 \\
\hline 1979 & 22.5 & -2.2 & 7.9 & 9.7 \\
\hline 1980 & 22.5 & -0.9 & 8.5 & 7.6 \\
\hline 1981 & 26.7 & 18.7 & 11.9 & 40 \\
\hline 1982 & 30.2 & 13.1 & 3.4 & 28.6 \\
\hline 1983 & 34.6 & 14.6 & 17.6 & 15.0 \\
\hline 1984 & 41.3 & 19.4 & 23.4 & 33.0 \\
\hline 1985 & 48.3 & 16.9 & 23.2 & -0.9 \\
\hline 1986 & 50.2 & 3.9 & 25.4 & 9.5 \\
\hline 1987 & 56.4 & 12.4 & 29.1 & 14.6 \\
\hline 1988 & 61.6 & 9.2 & 36.8 & 26.5 \\
\hline 1989 & 64.8 & 5.2 & 42.2 & 14.7 \\
\hline 1990 & 71.7 & 10.6 & 49.5 & 17.3 \\
\hline 1991 & 74.0 & 3.2 & 57.5 & 16.2 \\
\hline 1992 & 79.1 & 6.9 & 64.2 & 11.7 \\
\hline 1993 & 99.2 & 25.4 & 84.9 & 32.2 \\
\hline 1994 & 97.2 & -2.0 & 88.7 & 4.5 \\
\hline 1995 & 97.9 & 0.7 & 95.0 & 7.1 \\
\hline 1996 & 100.3 & 2.5 & 107.7 & 13.4 \\
\hline 1997 & 97.5 & -2.8 & 114.9 & 6.7 \\
\hline 1998 & 95.4 & -2.2 & 115.7 & 0.7 \\
\hline 1999 & 94.9 & -0.5 & 122.3 & 5.7 \\
\hline 2000 & 104.4 & 10.0 & 141.0 & 15.3 \\
\hline 2001 & 104.7 & 0.3 & 151.9 & 7.7 \\
\hline 2002 & 102.6 & -2.0 & 159.2 & 4.8 \\
\hline 2003 & 98.3 & -4.2 & 168.0 & 5.5 \\
\hline 2004 & 99.8 & 1.5 & 183.2 & 9.0 \\
\hline 2005 & 101.2 & 1.4 & 195.4 & 6.7 \\
\hline 2006 & 107.5 & 6.2 & 224.2 & 14.7 \\
\hline 2007 & 107.2 & -0.3 & 15.1 & 6.7 \\
\hline 2008 & 112.9 & 5.3 & 263.3 & 10.0 \\
\hline 2009 & 129.7 & 14.9 & 299.7 & 13.8 \\
\hline 2010 & 148.3 & 14.3 & 329.5 & 9.9 \\
\hline
\end{tabular}

Source: European Commission, 2013.

Indeed, Greek GDP during the period of the economic crisis (2000-2009) consists of 73\% private consumption (the largest percentage in EU-27), against a eurozone average of 58.8\% (Figure 9). The high percentage of consumption in the makeup of Greek GDP also resulted from the incessant annual increase of private and public consumption during the twenty-years that preceded the outbreak of the economic crisis (Tables 5 and 6). The point is to explore the contribution of various factors of the Greek Economy (investment, consumption, and external sector) to its growth. 


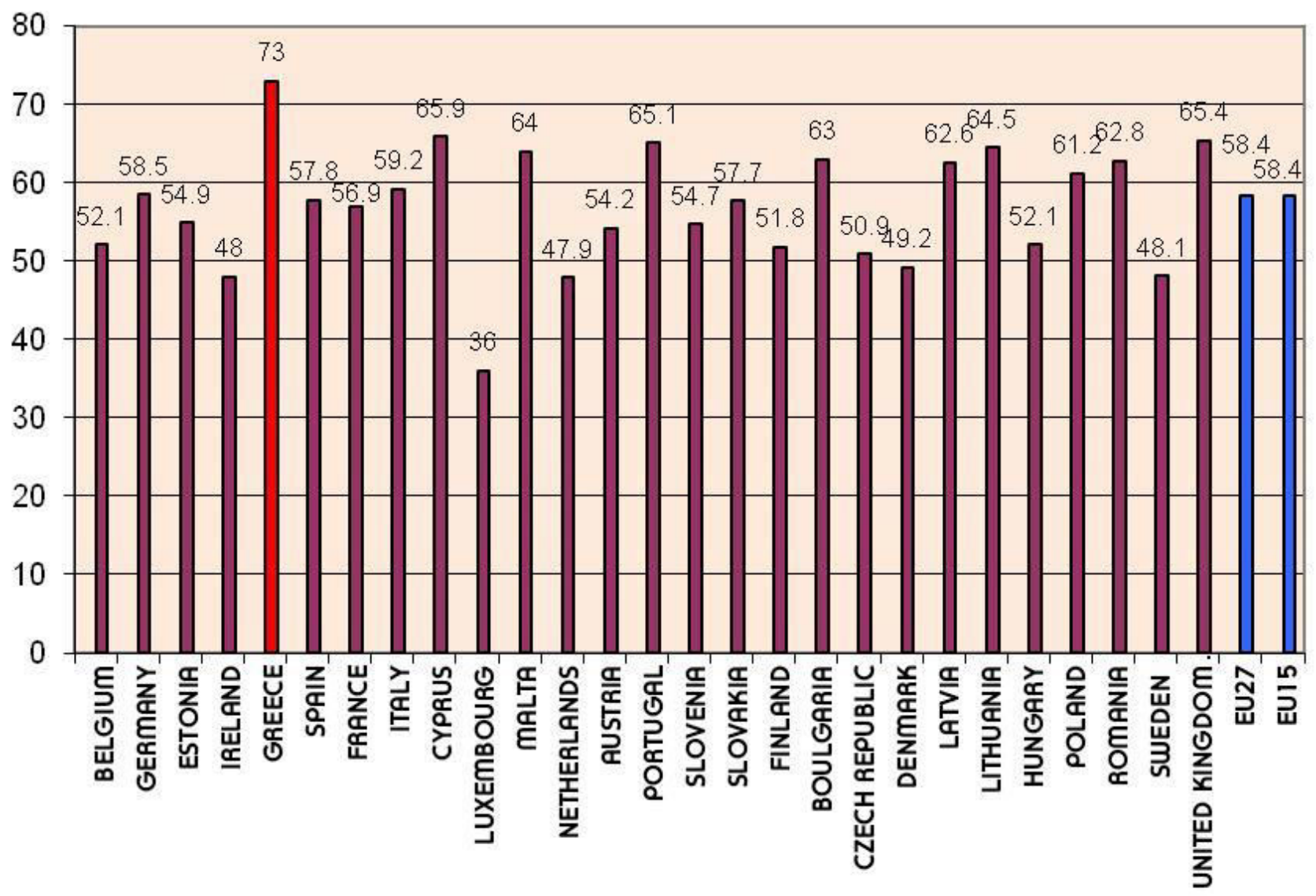

Figure 9. Private consumption to GDP ratio in EU countries, 2000-2009

Source: Anastasatos, 2009: 5

Table 5. Average annual percentage change of private consumption in Greece

\begin{tabular}{|c|c|c|c|c|c|c|c|}
\hline \multicolumn{8}{|c|}{ Private consumption (Average percentage y-o-y change) } \\
\hline Years & $\begin{array}{c}1992- \\
1996\end{array}$ & $\begin{array}{c}1997- \\
2001\end{array}$ & $\begin{array}{c}2002- \\
2006\end{array}$ & 2007 & 2008 & 2009 & 2010 \\
\hline $\begin{array}{c}\text { \% annual } \\
\text { change }\end{array}$ & 1.8 & 3.1 & 4.3 & 3.2 & -2.2 & -4.5 & \\
\hline
\end{tabular}

Source: European Economy Forecast Spring 2011, in Kotios and Pavlidis, 2012: 208-209

Table 6. Average annual percentage change of public consumption in Greece

\begin{tabular}{|c|c|c|c|c|c|c|c|}
\hline \multicolumn{7}{|c|}{ Public consumption (Average percentage y-o-y change) } \\
\hline Years & $\begin{array}{c}1992- \\
1996\end{array}$ & $\begin{array}{c}1997- \\
2001\end{array}$ & $\begin{array}{c}2002- \\
2006\end{array}$ & 2007 & 2008 & 2009 & 2010 \\
\hline $\begin{array}{c}\text { \% annual } \\
\text { change }\end{array}$ & 1.0 & 4.3 & 3.9 & 8.2 & 1.5 & 10.3 & -6.5 \\
\hline
\end{tabular}

Source: European Economy Forecast Spring 2011, in Kotios and Pavlidis, 2012: 208-9

\subsection{The contribution of various sectors to GDP growth}

In 2000-2008, the Greek economy experienced a period of uninterrupted strong economic growth, at an average annual rate of almost 3.4\% (Table 3), against an EU-16 average of $2.1 \%$. That said, the economy was growing faster than its long-term potential output growth rate suggested (Anastasatos, 2009: 4), as we will try to demonstrate here.

We will examine the contribution of the three variables of the GDP formula (GDP $=\mathrm{C}+\mathrm{I}+\mathrm{G}+\mathrm{NX}$ ), which are: consumption, investment, and net exports, to the economy's growth. When studying the contribution of private 
consumption to the growth of Greek GDP, we can see that it stood at $65.5 \%$, against a eurozone average of $52.7 \%$ (Anastasatos, 2009: 4). This sustains a vicious spiral of growth and consumption.

As a direct consequence of increased private consumption, savings suffered a steep fall of $-12 \%$ of GDP. In 1975 , savings had reached their peak, exceeding $25 \%$ of GDP, and started to decrease since then, without any interruption until the advent of the crisis. During Greece's EMU membership, savings in Greece remained at consistently negative rates, whereas the eurozone average stood at 5\% of GDP (EEAG 2011: 107). From 1989 onwards, this drop in the savings rate of the Greek economy is wholly attributed to the decrease in private savings from $27 \%$ in 1988 to $11 \%$ in 2008, thus leading to a scarcity of investment capital (Kotios and Pavlidis, 2011).

Total investment accounted for $23.4 \%$ of economic growth, as compared to an average of $21.2 \%$ in the eurozone. However, almost 1/3 of these investments concerned home construction (Anastasatos, 2009), as a result of the economy's specialisation in non-tradable goods (Christodoulakis, 2009), which crowds out the participation of productive and sustainable investments to the growth of the Greek economy, with obvious effects on supply, the composition of its productive fabric (Christodoulakis, 2009), and its international competitiveness, finally imposing a burden on the trade balance, as we will see from the examination of the economy's external sector.

The contribution of the external sector to Greece's economic progress prior to the crisis had been feeble. Indeed, exports of goods and services accounted for 30.8\% of economic growth, against a eurozone average of $87.5 \%$, highlighting the problem of limited openness, which is also a consequence of Greece's productive specialisation and reduced international competitiveness. Moreover, imports absorbed resources equivalent to $35.4 \%$ of economic growth, more-than-offsetting the positive contribution of exports. In other words, the external sector of the economy is a impediment to economic growth, as it deprives it of resources (Anastasatos, 2009).

Competitiveness, productivity, and per capita GDP in the Greek Economy

The economic growth experienced by Greece prior to the crisis did not match the competitiveness of its economy or the productivity of labour. Both figures are key determinants of the sustainability of economic growth.

The difference between per capita GDP and labour productivity in the Greek economy is both the outcome, and the cause, of the growth model that prevailed in Greece. Indeed, between 2000 and 2009, gross per capita income in Greece rose by $32 \%$, as compared to $11 \%$ in France, $16 \%$ in Germany, $2 \%$ in Italy, and 10\% in Portugal. In addition, "for the first time since 1981, Greece's living standard, measured in terms of private consumption, exceeded the EU15 average, rising from $98.5 \%$ to $107.9 \%$ of the average for the 15 -member European Union in 2008.” (Sidiropoulos, 2016: 245).

That said, the productivity of one hour of labour increased by 26\% in Greece during 2000-2009, as compared to 20\% in France, 18\% in Germany and Portugal, and 3\% in Italy. Thus, we can conclude that the growth of productivity (labour compensation) in Greece was not sufficient to justify such a large rise in incomes (Sidiropoulos, 2016: 245246).

The excessive and imbalanced rise in incomes resulted in price increases of $37 \%$ during the decade, as compared to $18 \%$ in Germany, 20\% in France, 26\% in Italy, and 29\% in Portugal, which adversely affected the competitiveness of Greek products and the trade balance, as mentioned above (Sidiropoulos, 2016: 245-246).

The study of the mismatch between the economy's competitiveness and per capita GDP for 2011, presented in Table 7, can lead to important conclusions. In terms of income, Greece was ranked 31 st in the world, whereas in terms of competitiveness it was ranked 90th. In order to understand the magnitude of this mismatch, we can just say that in terms of per capital GDP Italy was ranked 29th in the world, while in terms of competitiveness it was ranked 41 st. Spain was ranked 27 th and 37 th respectively; these are discrepancies that are not encountered in developed countries.

This fact corroborates the fact that Greece was living beyond its means (Naftemboriki, 2017). That said, the productive specialisation of the economy, as well as the elevation of consumption to a key determinant of growth, are to a great extent related to the way the banking system operates and the economy is financed.

Table 7. Country rankings in terms of competitiveness and per Capita GDP, 2011

\begin{tabular}{|c|c|c|c|}
\hline Country & Competitiveness & Per capita GDP & Change in place \\
\hline Greece & 90 & 31 & 59 \\
\hline Italy & 41 & 29 & 12 \\
\hline Spain & 37 & 27 & 10 \\
\hline Germany & 7 & 19 & -12 \\
\hline Portugal & 45 & 39 & 6 \\
\hline Belgium & 15 & 18 & -3 \\
\hline Bulgaria & 73 & 68 & 5 \\
\hline Albania & 78 & 95 & -17 \\
\hline
\end{tabular}


4.3 The role of the banking system in the formation of the growth model of the Greek economy

The way Greek banks operate feeds back into the consumption-based growth model of the Greek economy and undermined its macroeconomic stability. Indeed, in 1990-2000 the Greek banking system operated under strict regulations, and under conditions of high stability, while the loans to deposits ratio stood at 0.40 in 1993 and rose to almost 0.56 in 2001. ${ }^{3}$ Nonetheless, the Greek banking system, adjusted to the requirements of international competition and forced to better utilise its resources, embarked on a new period of operation during 2000-2008 (Drimpetas and Kalogeridis, 2016).

Indeed, the loans to deposits ratio rose from 0.64 at the beginning of the decade to 1.17 in 2010; this led to the reduction of safety margins and left commercial banks vulnerable to economic downturns. ${ }^{4}$ During the same period, the sector increased its assets by $133 \%$. Deposit growth stood at $50.62 \%$ and was disproportionate to the increase in loans, which stood at $176.25 \%$, thus pointing to the responsibility of the central bank as the supervisor of commercial banks. However, the loans were not designed to reform the productive fabric of the Greek economy (Drimpetas and Kalogeridis, 2016), as is the case with successful growth models, such as that of South Korea (Kohli, 2004). Based on the data presented in Table 8 we observe exactly the opposite, as the number of total loans extended to the three industries in which Greece enjoys a comparative advantage, i.e. agriculture ( $€ 1.5$ billion), tourism ( $€ 7.3$ billion) and shipping (€14.2 billion) stands at €23 billion, whereas consumer loans exceed €32 billion (Papadogiannis, 2012).

By comparing the data and examining the ratio of consumer loans to loans extended to manufacturing and construction, we can see that consumer loans exceeded loans to manufacturing by $45 \%$ and loans to construction by 215\% (Papadogiannis, 2012).

It is worth noting that consumer lending accounted for $14 \%$ of total loans, while mortgage lending accounted for a further $32 \%$. Therefore, $46 \%$ of total loans were extended for consumption, as well as for housing (Papadogiannis, 2012), which is considered to be an in-between good, covering both consumer and investment purposes (Orleans, 2010: 23), albeit as an investment good it does not contribute to sustainable growth. Responsibility for the above structure of lending does not only lie with commercial banks, but also with the Bank of Greece and the political leadership that failed to properly oversee the banking system.

Table 8. The structure of bank lending to various sectors of the Greek Economy until September 2012

\begin{tabular}{|c|c|}
\hline Loan amounts as per September 2012 & Amounts in $€$ million \\
\hline BUSINESSES & 110320.00 \\
\hline 1. Agriculture & 1503.00 \\
\hline 2. Industry & 22011.00 \\
\hline 2.1 Mining and quarrying. & 672.00 \\
\hline 2.2. Manufacturing & 21338.00 \\
\hline 3. Commerce & 22641.00 \\
\hline 4. Tourism & 7326.00 \\
\hline 5. Shipping & 14190.00 \\
\hline 6. Construction & 10146.00 \\
\hline $\begin{array}{l}\text { 8. Storage and transport, excluding shipping } 5944.00 \\
\text { 7. Electricity, gas, water supply }\end{array}$ & 1135.00 \\
\hline 9. Other & 18523.00 \\
\hline 9.1. Information and communication & 2885.00 \\
\hline 9.2. Real estate management & 4720.00 \\
\hline 9.3. Professional and other activities & 2873.00 \\
\hline 9.4. Other sectors & 8046.00 \\
\hline 10. Insurance companies and other financial institutions & 6902.00 \\
\hline $\begin{array}{l}\text { FREELANCE PROFESSIONALS, FARMERS AND SOLE } \\
\text { PROPRIETORSHIPS }\end{array}$ & 13957.00 \\
\hline $\begin{array}{c}\text { RETAIL CLIENS AND PRIVATE NON-PROFIT } \\
\text { INSTITUTIONS }\end{array}$ & 107541 \\
\hline 1. Housing & 75098.00 \\
\hline
\end{tabular}

\footnotetext{
3 This meant that, for every euro of deposits, banks extended total loans of 0.56 euros. It is well-known that the amount of loans extended by banks depends on the amount of deposits kept with them.

4. Although the Greek economic crisis was not caused by the banking system, the fiscal crisis and the resulting depression dealt a huge blow to the stability of the banks, which had failed to create margins of safety. That said, the need to bail out banks through recapitalisation exercises increased public debt.
} 


\begin{tabular}{|c|c|}
\hline 2. Consumer & 30634.00 \\
\hline 3. Other & 1809.00 \\
\hline Total Loans & 231818.00 \\
\hline
\end{tabular}

Source: Papadogiannis, 2012

In conclusion, the study of the data shows that the growth model prevailing in the Greek economy was based on the ability to fuel consumption with loans channelled to counterproductive spending. This was compounded by the fact that sustainable and export-oriented productive investment -which utilises the country's competitive advantages, increases the added value of the primary sector's output and, at the same time, lays the groundwork for the specialisation of the economy's productive base in advanced sectors- did not play the leading role.

Effects of the crisis on the Greek economy

This section will discuss the development of GDP, the public debt, the budget deficit, public investment, the trade balance, inflation, and unemployment in the Greek economy for the period 2007-2017 (Table 9). In 2007 and 2008, and after many years of accelerating growth rates, Greek economic growth faced a slowdown, as a result of the outbreak of the global financial crisis. After the onset of the Greek fiscal crisis in 2009 and 2010, and the resulting austerity policy and income cuts, the economy's GDP fell by a further 9.1\% in 2011, 7.3\% in 2012 and $3.2 \%$ in 2013 (at constant 2010 prices). In 2014, the Greek economy returned to positive growth rates of 0.7\%, while in 2015-2016 Greek GDP fell by a marginal 0.2-0.3\%. In 2017, there was hesitant growth of 1.4\%. Overall, the Greek economy has lost more than $30 \%$ of its income.

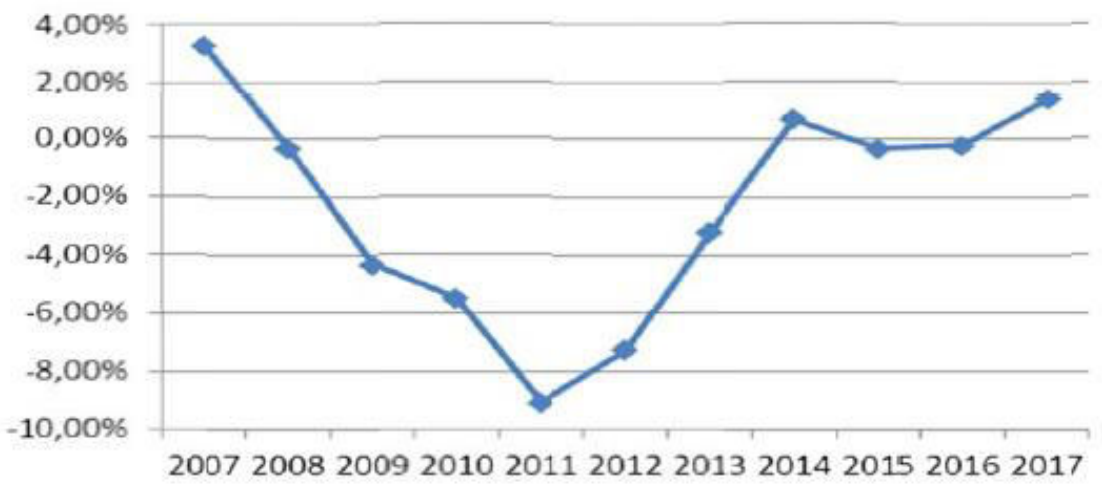

Source: Processing of ELSTAT data

Figure 10. Evolution of GDP, 2007-2010

Since the advent of the crisis, and for five years, the public deficit to GDP ratio does not show any signs of actual reduction, whereas there has been a significant contraction since 2015 . Inflation tended to fall since the beginning of the crisis, and this is very logical and consistent with market conditions. Up to 2015 it decreased, whereas in the next couple of years it was back on the rise. 


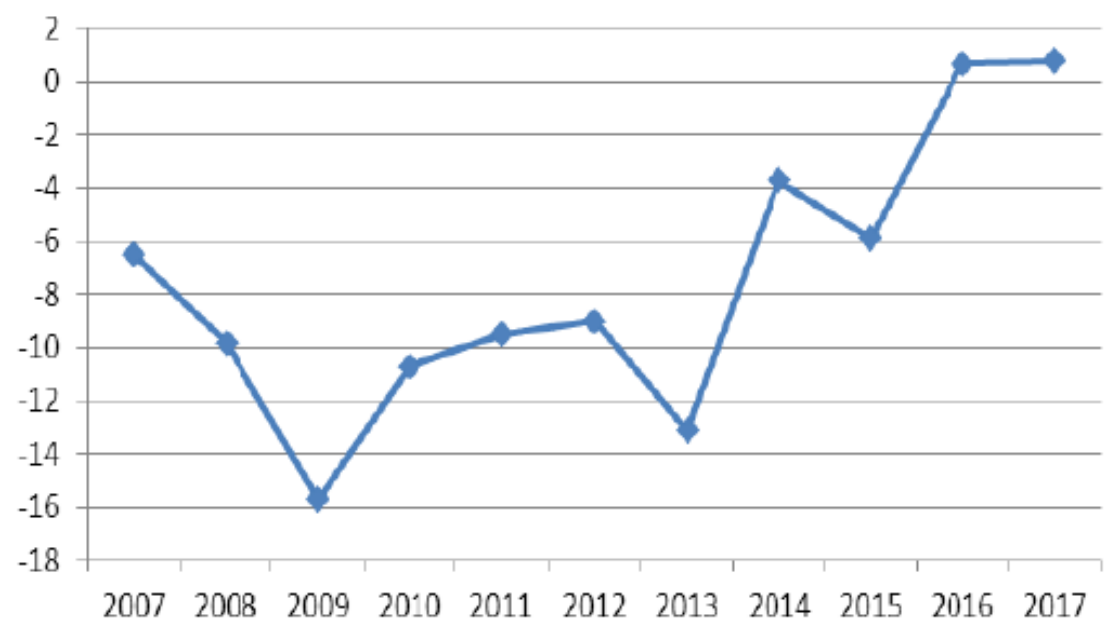

Figure 11. Public Deficit, 2007-2017

Source: Processing of ELSTAT data

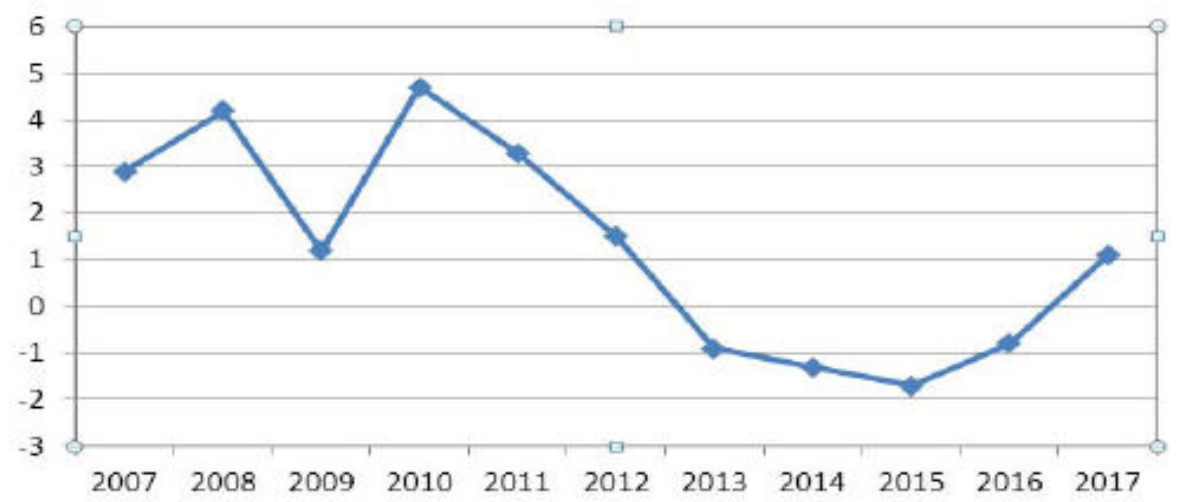

Figure 12. Inflation, 2007-2017

Source: Processing of ELSTAT data

Unemployment in Greece stood at relatively low rates of approximately $7.8 \%$ in 2008 , almost on a par with the eurozone average. After the advent of the crisis and until 2015, unemployment started to grow, until it peaked at $26.5 \%$, while in 2015 it fell slightly to $24.9 \%$. This slow decrease continued in the next couple of years, so that in 2017 , practically a decade after the onset of the crisis, unemployment still remained above $20 \%(21.5 \%)$. However, the total number of jobless individuals remains high, as it stood at 1027.00 thousand in 2017, as compared to 387.9 thousand in 2008 - in other words it trebled. The reduction in the absolute number of employed persons played a major role in the drop of the unemployment rate, as it fell from 4610.5 thousand in 2008 to 3752.7 in 2017 (Figures 13 and 14, and Table 10). Indeed, a KPMG study on the labour market and Greek migration showed that the total number of Greeks that left the country in 2008-2016 stands at almost 450,000. In their majority they are tertiary education graduates. 


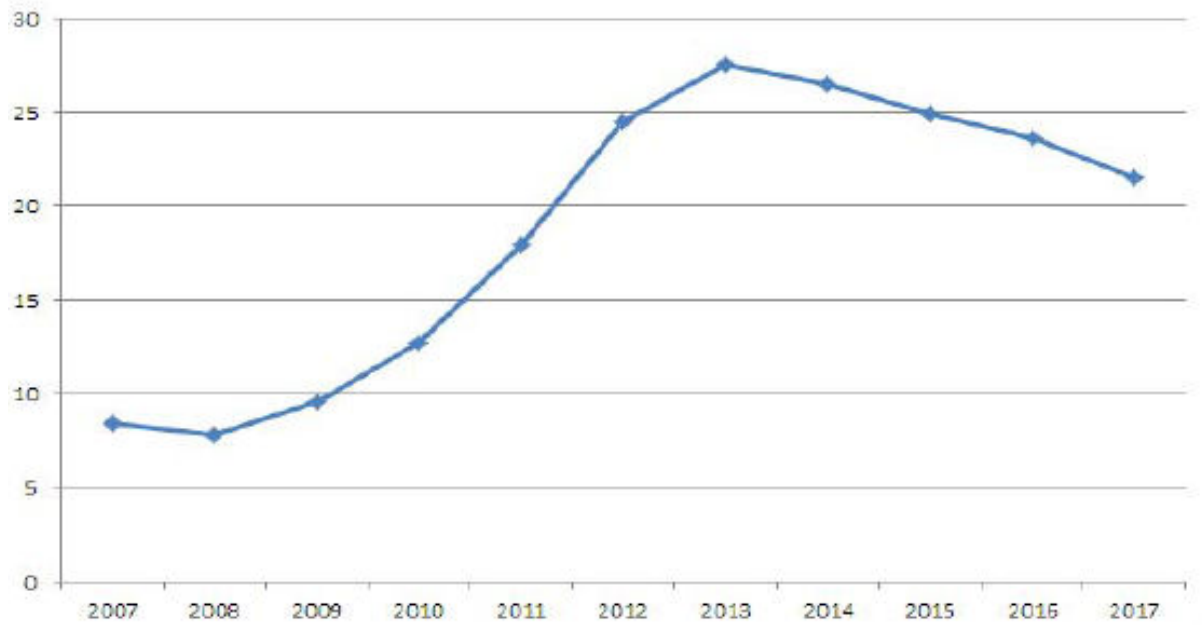

Figure 13. Unemployment, 2007-2017

Source: Processing of ELSTAT data

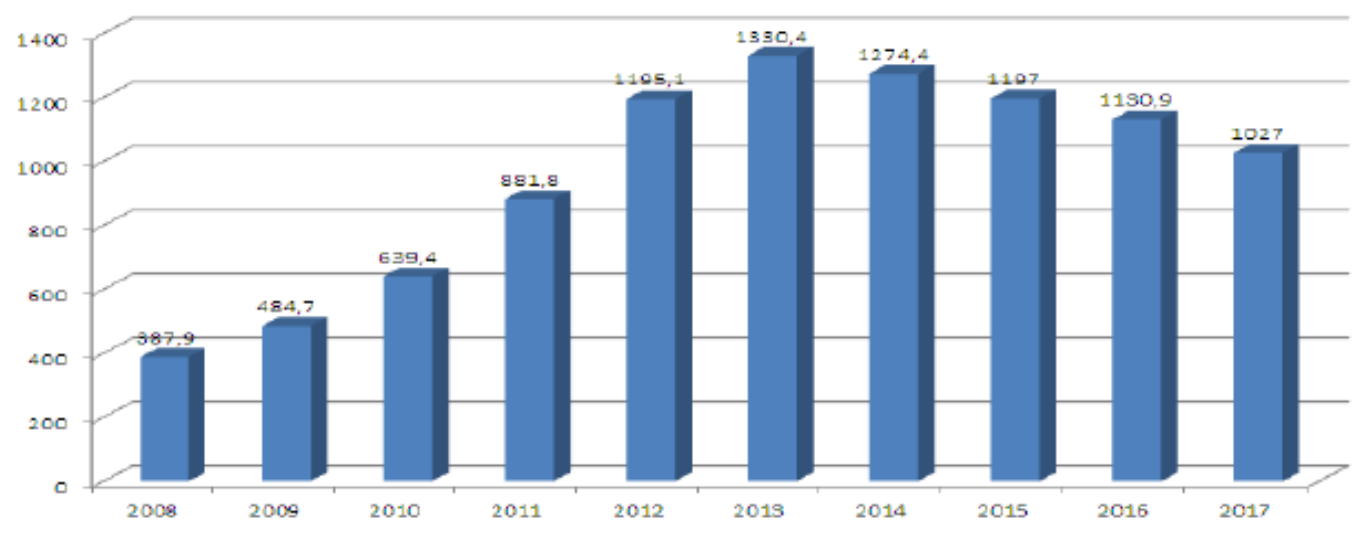

Figure 14. Unemployed individuals, 2008-2017

Source: Processing of data by the Population and

\subsection{Labour Market Statistics Division of ELSTAT}

The public investment sector shows remarkable stability during the decade. It started at $3.4 \%$ to $3.6 \%$ of GDP in 2008, showed a slight decrease up to 2012 (2.4\%), only to rise up again to $3.8 \%$ in 2015 . If, indeed, we take into account the fact that Greek GDP was declining throughout this period, we can conclude that no particular emphasis was placed on this sector, given that public investment includes community investments through NSRF programmes (Figure 15). Also, the trade balance remained in deficit, which, nonetheless fell from €42.5 billion in 2007 to almost half (€21.4 billion ) in 2017. This is mainly due to the very large decrease in imports, itself the result of the steep drop in domestic purchasing power, without any actual improvement of the economy's exports (Figure 16). 


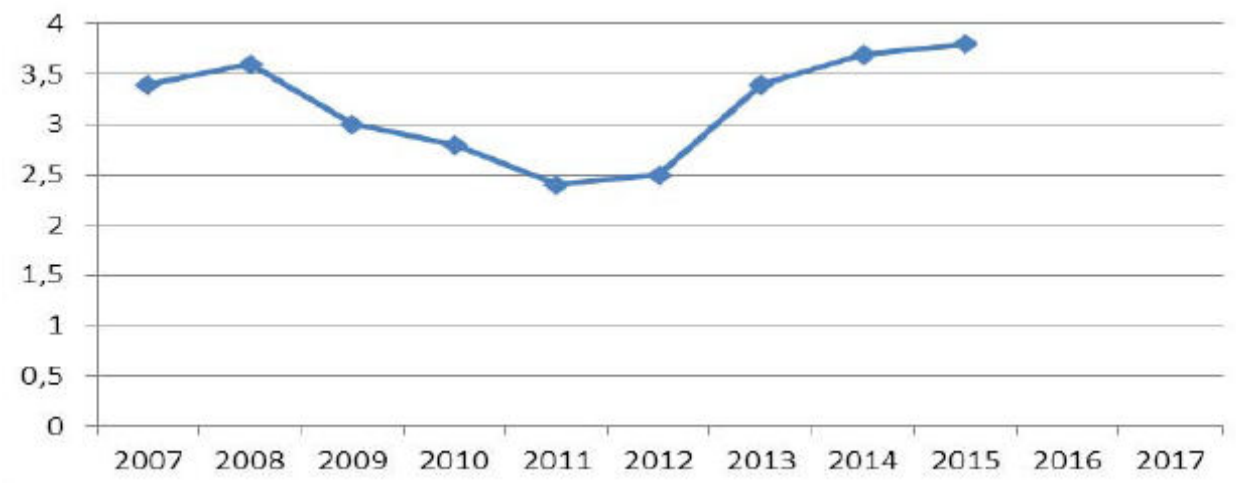

Figure 15. Public Investment, 2007-2017

Source: Processing of ELSTAT data

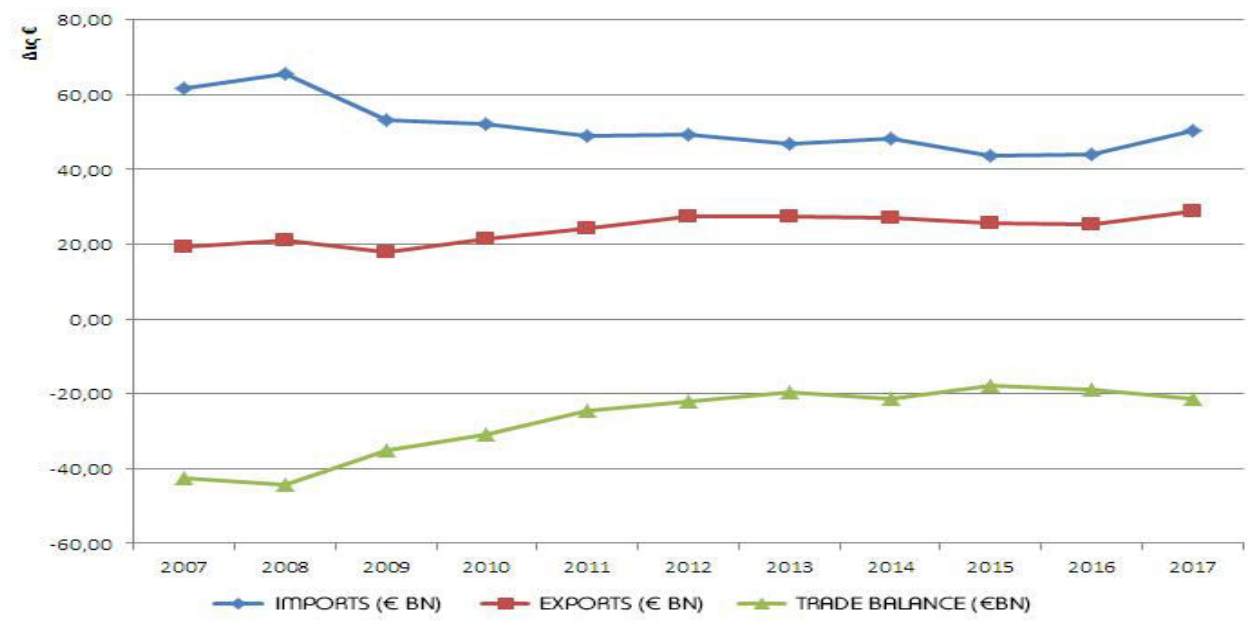

Figure 16. Imports- Exports - Trade Balance, 2007-2017

Source: Processing of ELSTAT data

Table 9. Evolution of key macroeconomic aggregates, 2007-2017

\begin{tabular}{|c|c|c|c|c|c|c|c|c|}
\hline & $\begin{array}{c}\text { Evolution } \\
\text { of GDP } \\
\text { (constant } \\
2010 \\
\text { prices) }\end{array}$ & $\begin{array}{c}\text { Budget } \\
\text { deficit } \\
\text { (\% of GDP) }\end{array}$ & $\begin{array}{c}\text { Average } \\
\text { annual } \\
\text { inflation }\end{array}$ & $\begin{array}{c}\text { Public } \\
\text { Investment } \\
\text { \% of GDP) }\end{array}$ & $\begin{array}{c}\text { Unemplo } \\
\text { yment }\end{array}$ & $\begin{array}{c}\text { Imports }(€ \\
\text { million) }\end{array}$ & $\begin{array}{c}\text { Exports }(€ \\
\text { million) }\end{array}$ & $\begin{array}{c}\text { Trade balance } \\
(€ \text { million) }\end{array}$ \\
\hline 2007 & $3.3 \%$ & -6.5 & 2.9 & 3.4 & 8.4 & $61,857.3$ & $19,313.4$ & $-42,543.90$ \\
\hline 2008 & $-0.3 \%$ & -9.8 & 4.2 & 3.6 & 7.8 & $65,528.3$ & $21,227.7$ & $-44,300.60$ \\
\hline 2009 & $-4.3 \%$ & -15.7 & 1.2 & 3.0 & 9.6 & $53,135.1$ & $18,015.1$ & $-35,120.00$ \\
\hline 2010 & $-5.5 \%$ & 4.7 & 2.8 & 12.7 & $52,147.5$ & $21,299.4$ & $-30,848.10$ & $24,377.3$ \\
\hline 2011 & -10.7 & $-9.1 \%$ & -9.5 & 3.3 & 2.4 & 17.9 & $48,891.5$ & $-24,514.20$ \\
\hline 2012 & $-7.3 \%$ & -9 & 1.5 & 2.5 & 24.5 & $49,537.1$ & $27,577.0$ & $-21,960.10$ \\
\hline 2013 & $-3.2 \%$ & -13.1 & -0.9 & 3.4 & 27.5 & $46,996.5$ & $27,294.4$ & $-19,702.10$ \\
\hline 2014 & $0.7 \%$ & -3.7 & -1.3 & 3.7 & 26.5 & $48,327.1$ & $27,118.4$ & $-21,208.70$ \\
\hline 2015 & $-0.3 \%$ & -5.9 & -1.7 & 3.8 & 24.9 & $43,602.1$ & $25,824.9$ & $-17,777.20$ \\
\hline
\end{tabular}




\begin{tabular}{|c|c|c|c|c|c|c|c|c|}
\hline 2016 & $-0.2 \%$ & +0.7 & -0.8 & & 23.6 & $44,187.4$ & $25,463.5$ & $-18,723.90$ \\
\hline 2017 & $1.4 \%$ & +0.8 & 1.1 & & 21.5 & $50,273.0$ & $28,843.1$ & $-21,429.90$ \\
\hline
\end{tabular}

Source: Processing of ELSTAT data

Table 10. Population aged 15 and above, by employment status

\begin{tabular}{|c|c|c|c|c|c|c|c|c|c|c|}
\hline & 2008 & 2009 & 2010 & 2011 & 2012 & 2013 & 2014 & 2015 & 2016 & 2017 \\
\hline Employed & 4610.5 & 4556 & 4398 & 4054.4 & 3695 & 3536.2 & 3536.2 & 3610.7 & 3673.6 & 3752.7 \\
\hline Unemployed & 387.9 & 484.7 & 639.4 & 881.8 & 1195.1 & 1330.4 & 1274.4 & 1197 & 1130.9 & 1027 \\
\hline $\begin{array}{c}\text { Non- } \\
\text { economically } \\
\text { active }\end{array}$ & 4436.8 & 4390.4 & 4370.3 & 4436.7 & 4454.7 & 4466 & 4438.9 & 4438.9 & 4408.3 & 4397.2 \\
\hline $\begin{array}{c}\text { Employment } \\
\text { Rate }\end{array}$ & 48.9 & 48.3 & 46.7 & 43.3 & 39.5 & 37.7 & 38.1 & 39 & 39.9 & 40.9 \\
\hline $\begin{array}{c}\text { Unemployme } \\
\text { nt rate }\end{array}$ & 7.8 & 9.6 & 12.7 & 17.9 & 24.4 & 27.5 & 26.5 & 24.9 & 23.5 & 21.5 \\
\hline
\end{tabular}

Source: Population and Labour Market Statistics Division of ELSTAT

The economy's spiralling into prolonged depression and the worsening of macroeconomic aggregates have an impact on both the society and the people. However, studying the social consequences of the depression is beyond the scope of this analysis. We will only refer to the at-risk-of-poverty rate in Greece, as an indication of the social repercussions of the Greek economic crisis. Figure 17 shows the at-risk-of-poverty rate (calculated on the basis of the poverty line for the year 2005), which from $18.3 \%$ rose to $42 \%$ in 2014 and remained at these levels until 2016 , pointing to the severity of the situation.

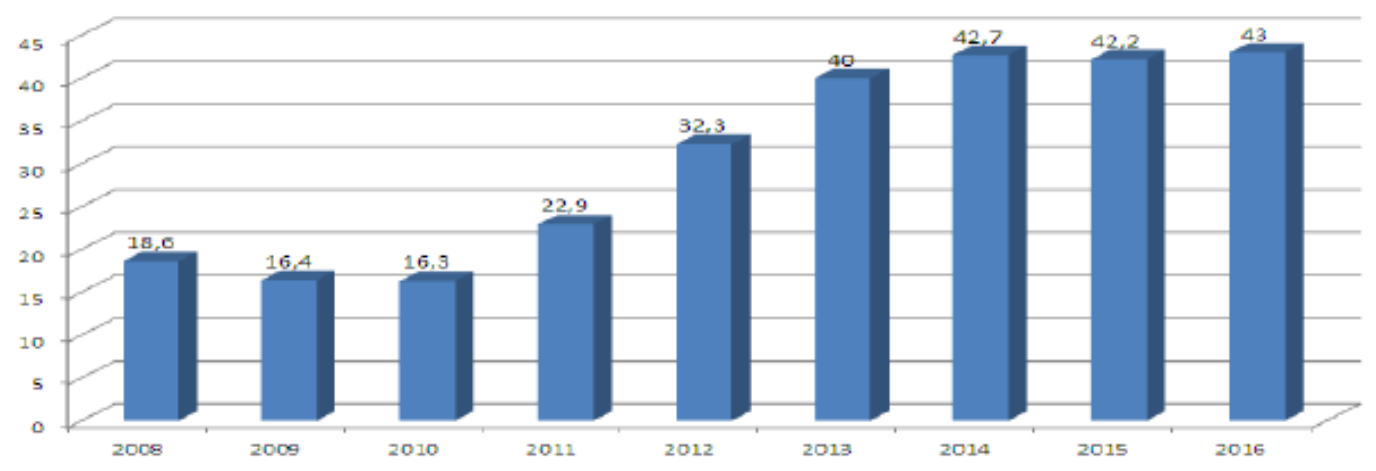

Figure 17. At-risk-of-poverty rate, based on the 2005 poverty line

Source: Processing of ELSTAT data

\section{Comparison of Consequences for the Greek and US Economies}

In fact, the magnitude of the effects of the Greek crisis on the real economy, as well as the duration of the depression, are comparable with the corresponding effects that were observed during the Great Depression of 1929 (Alderman et. al, 2017). This is corroborated by the comparison of key macroeconomic aggregates, which is presented below.

During the Great Depression the US economy suffered a cumulative GDP drop of $26 \%$, whereas in the case of the Greek depression income contraction stood at almost 29.5\% up to 2017 (Figure 18). As regards recovery times, the US economy started to recover after five years of incessant depression, while post-depression economic growth was strong at almost $10.8 \%$ (Figure 6). In Greece, the depression lasted for 7 years (Figure 18), while economic recovery is feeble, a fact that does not bode well for the sustainability of economic growth (Table 9). 


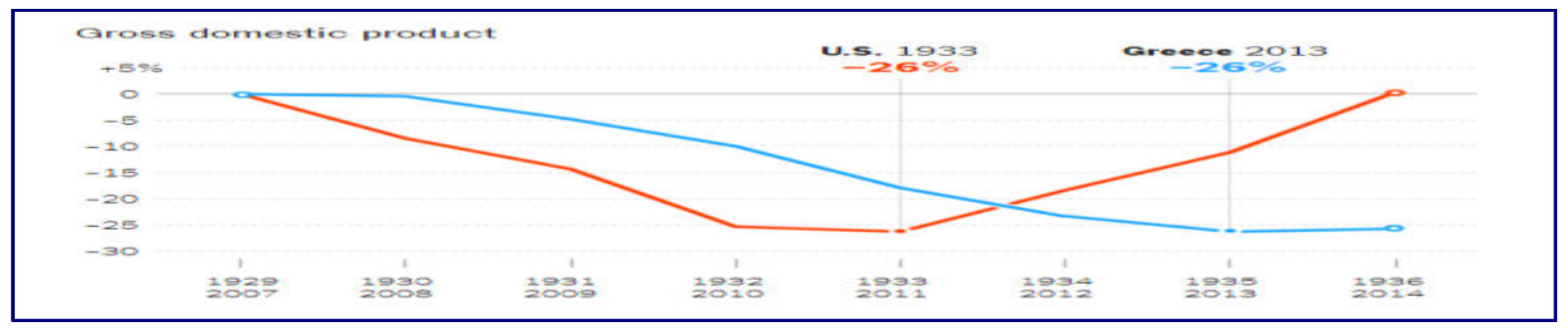

Figure 18. Percentage change of GDP since 1929 in the US and since 2007 in Greece.

Source: New York Times, U.S. Bureau of Economic Analysis; Eurostat; U.S. National Bureau of Economic Research; Bloomberg

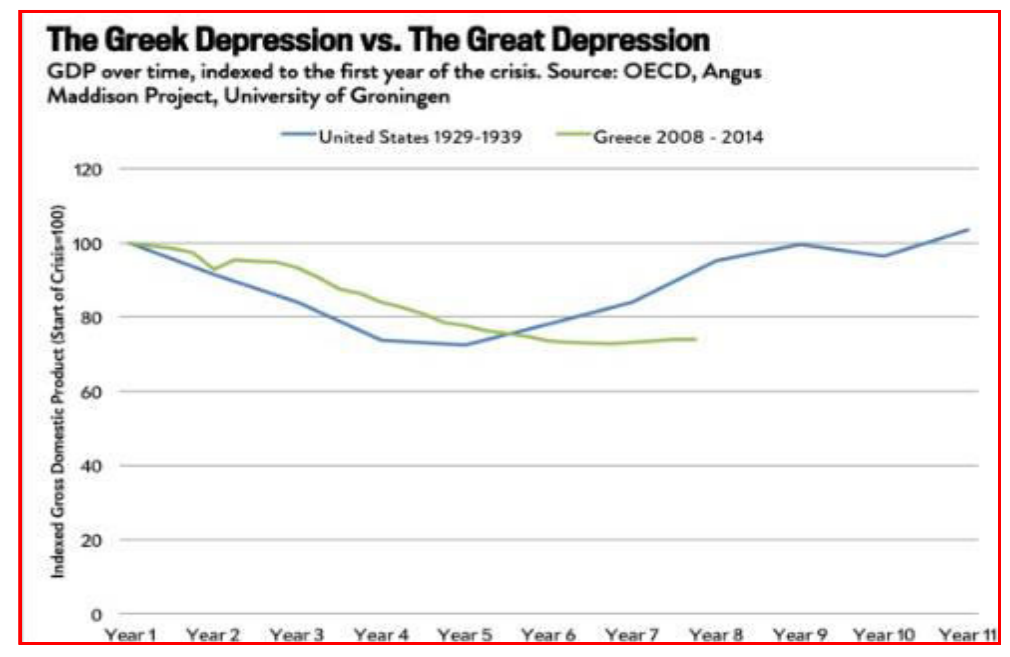

Figure 19. Comparison between the Greek and the Great Depression

Source: New York Times, U.S. Bureau of Economic Analysis; Eurostat; U.S. National Bureau of Economic Research; Bloomberg

Unemployment in the US had been rising for 3 consecutive years, reaching its peak in 1933 at $26 \%$ and improving significantly since then, as it fell by $10 \%$ in just one year, and in 4 years was almost back to its pre-crisis levels of approximately 12\%. In Greece, unemployment kept rising for 6 years, reaching almost $28 \%$ at its peak, while its reduction is not significant and is, to a great extent, questionable, as discussed above (Figure 20 and Table 10). It is worth noting that up to this date unemployment in Greece remains the highest in Europe (Figure 21). The prolonged depression led to the contraction of the labour force in Greece, something that did not occur in the US (Figures 22 and 23).

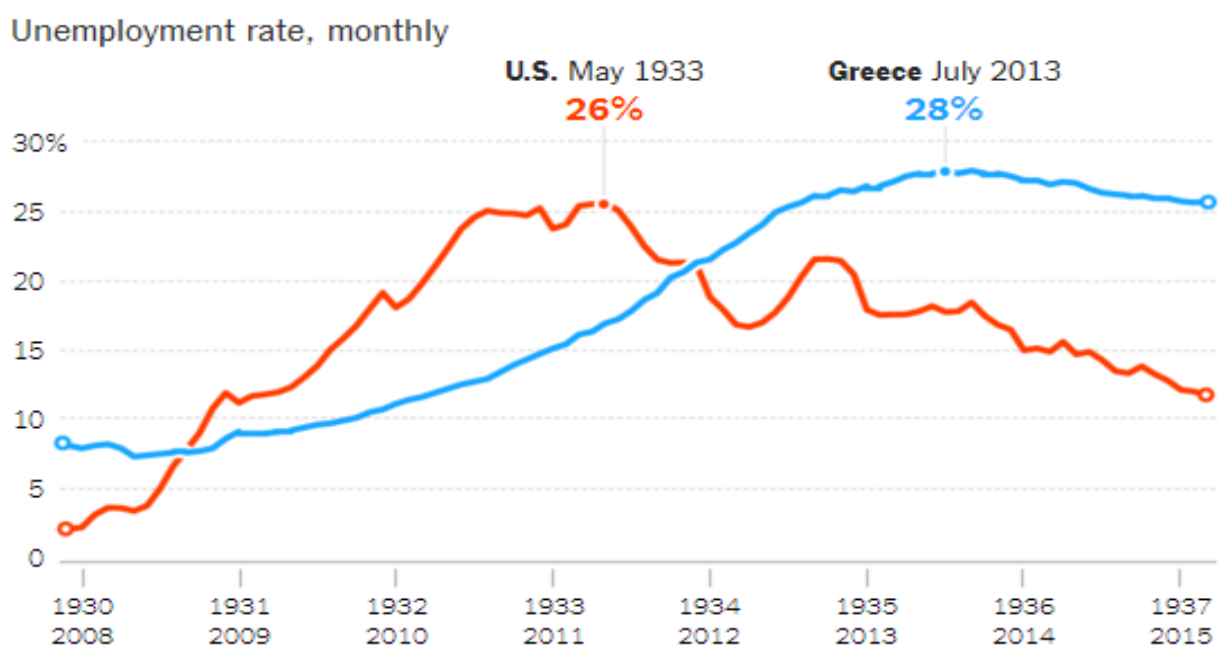

Seasonally adjusted 
Figure 20. Unemployment

Source: New York Times, U.S. Bureau of Economic Analysis; Eurostat; U.S. National Bureau of Economic Research; Bloomberg

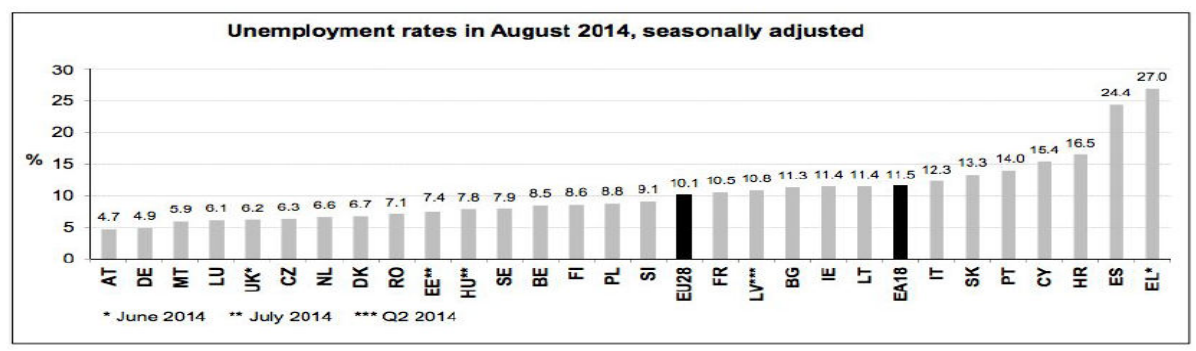

Figure 21. Unemployment per European country, August 2014

Source: Business Insider, Eurostat

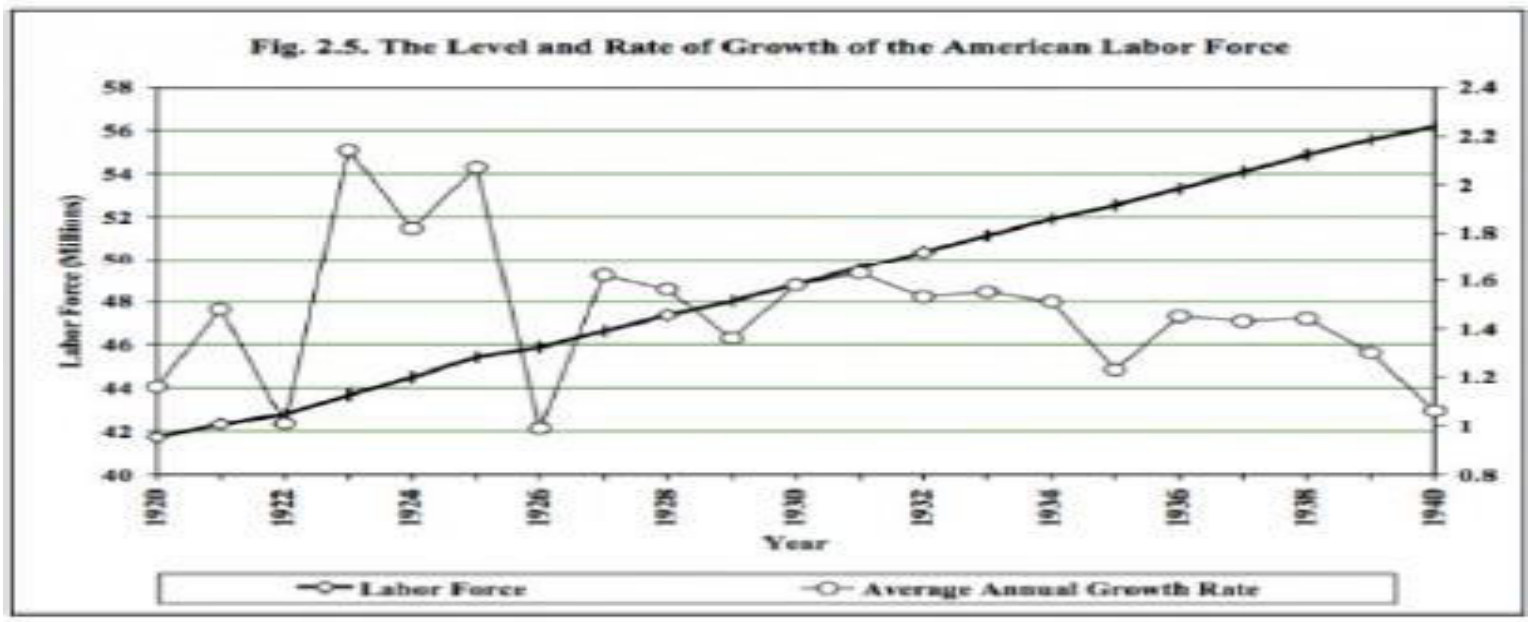

Figure 22. US Labour Force and Growth rate, 1920-1940

Source: Business Insider, The American Economy in the 2oth Century, FRED

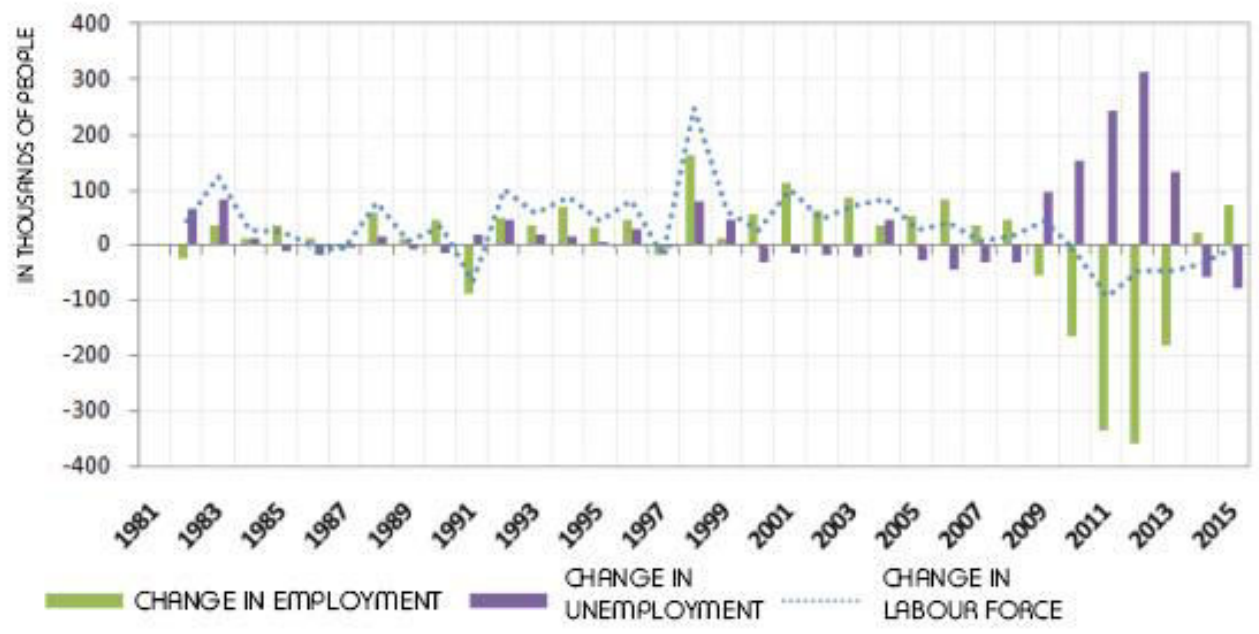

Figure 23. Greece: Changes in labour force, employment, and unemployment

Source: ELSTAT, Press release, February 2017

The Greek stock market fell more steeply than the US one, as the largest drop in the case of Greece reached $91 \%$ in June 2012, whereas in the US it reached 89\%. In any case, our focus should be on the recovery of the stock market. 
In the US, recovery was strong, immediately after the lowest point of the trough. In Greece, stability in the stock market has not yet been recovered, demonstrating that the country's reliability in the eyes of the investors remains precarious, a fact that does not give rise to prospects for the country's overall economic recovery (Figure 24).

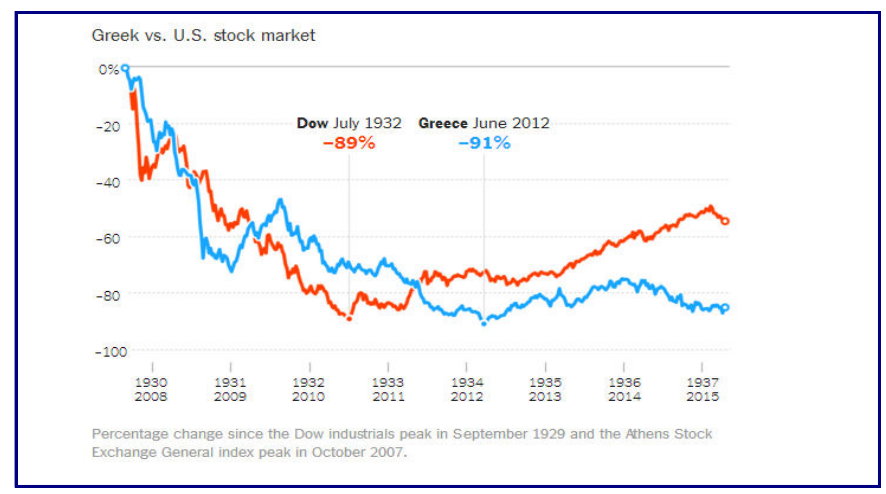

Figure 24. Greek and US stock markets

Source: New York Times, U.S. Bureau of Economic Analysis; Eurostat; U.S. National Bureau of Economic Research; Bloomberg

\section{Conclusions}

The comparison of the two crises on the basis of their effects on the real economy demonstrates that the Greek crisis had harsher consequences than the US crisis, taking into account its impact on key macroeconomic aggregates susch as the income loss, the duration of the depression, the unemployment, the stock market index. Taking into account all the above macroeconomic fundamentals It is easy to conclude that the recent Greek depression that resulted from the fiscal crisis has been harsher than the Great Depression caused by the financial crisis of 1929 in the US.

Moreover, of particular importance is the feeble recovery of all economic aggregates in the case of the Greek economy as compared to the US economy, raising concerns about the ways the crisis was dealt and the overall management of the Greek economic crisis up to now. In addition, we ought to focus on the lack of national planning and a carefully planned actual and sustainable development of the real economy and, by extension, economic growth. 
Agglieta, M., 2009, The Economic Crisis (in Greek), Translation A. D. Papapgiannidis Athens, Polis.

Alderman, et. al., 2015. Is Greece Worse Off Than the U.S. During the Great Depression? Available at: https://www.nytimes.com/interactive/2015/07/09/business/international/is-greece-worse-off-than-the-usduring-the-great-depression.html (accessed November 25, 2017).

Alexakis, Ch. and Xanthakis, M., 2008, Behavioral Finance (in Greek), Athens, Stamoulis.

Alogoskoufis, G., 2013, Macroeconomics and Politics in the Accumulation of Greece's Debt: 1975-2009 (in Greek), Athens, Athens University of Economics and Business.

Anastasatos, T., 2009, "Towards a new Greek growth model: investment and extroversion" (in Greek), Eurobank Research, Economy and Markets.

Argitis, G., 2010, Bankruptcy and Economic Crisis (in Greek), Athens, Alexandria.

Bernanke, B., 1994, “The Macroeconomics of the Great Depression: A Comparative Approach”, NBER, Working Paper No. 4814 .

Bernanke, B., 2000, To understand the Great Depression is the Holy Grail of macroeconomics, Essays on the Great Depression, Princeton, Princeton University Press.

Crafts, N. and Fearon, P., 2013, The Great Depression of the 1930s: lessons for today, Oxford, Oxford University Press.

Dida, B. and Grossman H.I., 1988, "The theory of rational bubbles in stock prices", The Economic Journal, Vol. 98, (392), pp. 746-754.

Dimeli, S., 2010, Macroeconomic aggregates and growth rates of the Greek economy (in Greek), Athens, Athens University of Economics and Business.

Drimpetas, E. and Kalogeridis, N., 2016, “The Dynamics and Role of Greece's Banking system, 2000-2010”, Roukanas, S. \& Sklias, P., The Greek Political Economy, 2000-2015, Delft, Eburon, p.p. 66-95.

Economics Essays, 2012, "Causes of Great Depression", https://econ.economics help.org/2008/10/causes-of-greatdepression.html (August 2018).

Economics of Everyday life (in Greek), https://www.dailyeconomics.gr/oikonomikoi-oroi/chrhmatopistwtikh-krish (November 2018).

EEAG, 2011, "The EEAG Report on the European Economy., A New Crisis Mechanism for the Euro Area", CESifo, pp.71-125.

European Commission, "Annual Macro-economic Database", http://eu.economy_finance/ameco//user/serie/SelectSerie.cfm (October 2017).

Flood, R. and Hodrick, R., 1990, "On testing for speculative bubbles", The Journal of Economic Perspective, 2, 85-101.

Flood, R.and Garber, P., 1984, Speculative bubbles, speculative attacks, and policy switching, USA, MIT Press.

Galbraight, J.K., 2000, The Great Crash of 1929 (in Greek), Athens, Livanis.

Howard, S., 1991, The business cycle. Growth and crisis under capitalism, New Jersey, Princeton University Press.

IMF, 2017, "Country Information", www.imf.org/external/country/index.htm, (October 2017).

IMF, 2017, "Data and Statistics", www.imf.org/external/external/data.htm. www.imf.org/external/external/ns/cs.aspx?id=28.htm, (October 2017).

Kapstein, E., 1994, Governing the global economy, international finance and the state, Massachusetts,Cambridge. USA, Harvard university press.

Karavitis, N., 2008, Public Debt and Deficit (in Greek), Athens, Dioniko publications.

Katrakilidis, C. and Tabakis, N., 2006, "Greek Budget Deficits, Structural Breaks and the Concept of Sustainability: New Econometric Evidence" Economics and Business Review, 3, pp. 263-278.

Kazakos, P. et. al., 2016, Greece's public debt (in Greek), Athens, Papazisis Publications.

Keynes, J. M., 2001, The General Theory of Employment Interest and Money (Greek translation by Th. Athanassiou), Athens, Papasizis Publications.

Kindleberger, C., 1978, Manias, Panics, and Crashes: A History of Financial Crises, New Jersey, Macmillan.

Knoop, T., 2008, Modern financial macroeconomics. Panics, crashes and crises, Oxford, Blackwell publishing.

Knoop, T., 2004, Recessions and Depressions. Understanding business cycles, London, Praeger.

Kohli, A., 2004, State-Directed Development: Political Power and Industrialization in the Global, Periphery Cambridge, Cambridge University Press.

Kotios, A. and Pavlidis, G., 2012, Systemic or Policy Crises? (in Greek), Athens, Rosili Publications.

Krugman, P., 2015, "Weimar and Greece, Continued", The New York Times, https://krugman.blogs.nytimes.com/2015/02/15/weimar-and-greece-continued, (February 2015).

Krugman, P., 2008, The Return of Depression Economics and the Crisis of 2008 (Greek translation by Ariadne Alavanou), Athens, Kastaniotis.

Lakasas, A., 2017. Brain-drain costs 15.3 billion (in Greek), Kathimerini newspaper, Available at: http://www.kathimerini.gr/946827/article/epikairothta/ellada/153-dis-to-kostos-toy-brain-drain. (accessed November 25, 2017).

Makrydakis, et. al., 1999, Forecasting: Methods and Applications, New York, Wiley.

Maraveyas N., 2009, "Ten years of EMU: convergence divergence and new policy priorities" The Hellenic Observatory LSE. Paper No 22.

Milward, B., 2000, "What is structural adjustment?”, Mohan, G., Brown, E., Milward, B. and Zack-Williams A.B., Structural adjustment: theory, practice and impacts, London, Routledge.

Minsky, H., 1982, Can "It" Happen Again: Essays on instability and finance?, Journal of economic issues, 18.

Naftemboriki newspaper, 2017, "Per capita GDP inconsistent with Greek productivity" (in Greek). https://www.pressreader.com/greece/naftemporiki/20170329/281560880628764, (October 2017).

Orleans, A., 2010, "From euphoria to panic" (Greek translation by Babis Papadimitriou), Askenazy, P., Daniel, C., 
Nouvelles réflexions sur la crise financière, Athens, Polis publications.

Pantelakis, N., 1995, Public borrowing (in Greek), Athens, National Bank of Greece Cultural Foundation.

Papadimitriou, P. and Hadjigiannakis G., 2010, "The fiscal situation in Greece: In the end, it is all our blame” (in Greek), Minutes of the International conference on international Business, 2010 Thessaloniki, Greece.

Papadogiannis, G., 2012, "Greek banks extend loans for consumption and not production" (in Greek). http://www.kathimerini.gr/474143/article/oikonomia/ellhnikh-oikonomia/daneia-sthn-katanalwsh-kai-oxi-sthnparagwgh-apo-tis-ellhnikes-trapezes, ( July 2017).

Pauly, L., 2005, “The political economy of international financial crises”, Ravenhill, S., Global political economy, N. York, Oxford University Press, p.p.225-245.

Pettinger, T., 2012, "Causes of Great Depression", https://econ.economicshelp.org/2008/10/causes-of-greatdepression.html, (October 2018).

Pinto, B. and Prasad, M., 2009, "Lessons from market-access countries on public debt sustainability and growth", Braga C. and Domeland, D., Debt relief and beyond: Lessons learned and challenges ahead, Washington, The World Bank, pp.181-201.

Rapanos, V., 2008, "Economic theory and fiscal policy: Fiscal institutions in Greece” (in Greek), Giannitsis, T., In search of a Greek growth model, Athens, Papazisis Publications, pp. 159-180.

Reinhart, C. and Rogoff, K., 2008, "This Time is Different: A Panoramic View of Eight Centuries of Financial Crises", NBER Working Paper No 13882.

Reinhart, C. and Rogoff, K., 2009, “The Aftermath of Financial Crises”., American Economic Review, 99, pp.466-472.

Reinhart, C.M. And Roggof, K.S., 2010, "From financial crash to debt crisis", NBER, Working Paper 15795.

Sidiropoulos, M., 2016, "Economic policy impetus to post-EMU Greece’s economic growth",: Roukanas, S. and Sklias, P., The Greek Political Economy. Delft, Eburon, pp. 303-318.

Smiley, G., 2007, "The U.S. Economy in the 1920s.", https://eh.net/encyclopedia/the-u-s-economy-in-the-1920s/. (accessed October 5, 2018).

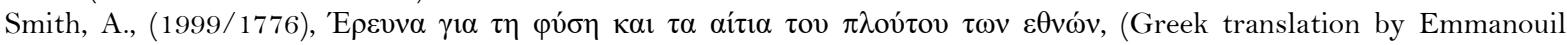
Kalitsounakis), Athens, Papazisis Publications.

Spartiotis, D. and Stournaras, I., 2010, Fundamental Causes of the collapse of banks and financial markets, the experience of 2007-2008 (in Greek), Athens, Gutenberg.

Walh, P., 2009, "Food speculation - The main factor of the price bubble in 2008", Briefing Paper, www.weed-online.org, ( July 2012).

Woodward, D., 1992, Debt and adjustment: an introduction, London, Pinter publishers.

This is an Open Access article distributed under the terms of the Creative Commons Attribution Licence 